\title{
Impacts of warm and cold situations in the Mediterranean basins on the West African monsoon: observed connection patterns (1979-2006) and climate simulations
}

\author{
Bernard Fontaine $\cdot$ Javier Garcia-Serrano $\cdot$ Pascal Roucou $\cdot$ Belen Rodriguez-Fonseca \\ Teresa Losada · Fabrice Chauvin · Sébastien Gervois · Sivarajan Sijikumar • \\ Paolo Ruti · Serge Janicot
}

Received: 16 December 2008/Accepted: 19 May 2009/Published online: 11 June 2009

(C) The Author(s) 2009. This article is published with open access at Springerlink.com

\begin{abstract}
Using both empirical and numerical ensemble approaches this study focuses on the Mediterranean/West African relationship in northern summer. Statistical analyses utilize skin temperature, sea surface temperature, in situ and satellite rainfall, outgoing longwave radiation (OLR) observations and reanalyzed data winds and specific humidity on isobaric surfaces. Numerical investigations are based on a large set of sensitivity experiments performed on four atmospheric general circulation models (AGCM): ARPEGE-Climat3, ECHAM4, LMDZ4 and UCLA7.3. Model outputs are compared to observations, discussed model by model and with an ensemble (multi-model) approach. As in previous studies the anomalous Mediterranean warm events are associated with specific impacts
\end{abstract}

This paper is a contribution to the special issue on West African Climate, consisting of papers from the African Multidisciplinary Monsoon Analysis (AMMA) and West African Monsoon Modeling and Evaluation (WAMME) projects, and coordinated by Y. Xue and P. M. Ruti.

B. Fontaine $(\bowtie) \cdot$ P. Roucou $\cdot$ S. Sijikumar

Centre de Recherches de Climatologie,

CNRS/University of Burgundy, Dijon, France

e-mail: fontaine@u-bourgogne.fr

J. Garcia-Serrano · B. Rodriguez-Fonseca · T. Losada

Universidad Complutense de Madrid, Madrid, Spain

S. Gervois - S. Janicot

Institut Pierre-Simon Laplace/LOCEAN, CNRS/IRD/Paris VI,

Paris, France

F. Chauvin

Centre National de Recherches Météorologiques,

CNRS/Météo-France, Toulouse, France

P. Ruti

Environmental and Energy Research Institute, Rome, Italy over the African monsoon region, i.e., a more intense monsoon, enhanced flux convergence and ascendances around the ITCZ, a strengthening of low level moisture advection and a more northward location of ascending motion in West Africa. The results show also new features (1) thermal variability observed in the two Mediterranean basins has unalike impacts, i.e. the western Mediterranean covaries with convection in Gulf of Guinea, while the eastern Mediterranean can be interpreted as Sahelian thermal-forcing; (2) although observations show symmetry between warming and cooling, modelling evidences only support the eastern warming influence; (3) anomalous East warm situations are associated with a more northward migration of the monsoon system accompanied by enhanced southwertely flow and weakened northeasterly climatological wind; (4) the multi-model response shows that anomalous East warm surface temperatures generate an enhancement of the overturning circulation in low and high levels, an increase in TEJ (Tropical Eeasterly Jet) and a decrease in AEJ (African Eeasterly Jet).

\section{Introduction}

The potential role of surface temperatures over the Mediterranean in West African climate dynamics has been largely less investigated than that of the tropical Atlantic or of the El Nino Southern Oscillation (ENSO) phenomenon. Moreover these investigations are recent and hence only based on a few empirical and/or numerical studies. The seminal work, based on observed (1947-96) data, long-term atmospheric general circulation model (AGCM) simulations and idealized experiments forced by warmer (colder) sea surface temperatures (SSTs) in the Mediterranean, has been published by 
Rowell in 2003. It demonstrates that "in years when the Mediterranean is warmer than average the Sahel tends to be wetter than normal" (and vice versa) with a significant positive correlation $(r=+0.47)$ between the whole Mediterranean SST and JAS Sahel during 1947-1996.

The same year Fontaine et al. (2003) used observational precipitation data and atmospheric reanalyses on the period 1968-1998 for studying moisture fluxes. They founded that part of the moisture fluxes vertically integrated in the layers $1,000-300 \mathrm{hPa}$ or $1,000-925 \mathrm{hPa}$ advected into the West African Monsoon area originates from the Mediterranean Sea and Central Africa and presents significant relationship with atmospheric water budget over the Sahelian belt during the rainy season. Contemporary, Raicich et al. (2003) found that the Sahel rainfall anticorrelates with sealevel pressure in the southeastern Mediterranean basin, suggesting the physical mechanism might involve variations in the local inter tropical convergence zone (ITCZ).

More recently, Peyrillé et al. (2007) analyzed the effect of changes in SST in the Mediterranean and the Gulf of Guinea using a 2-d zonally-symmetric model (30S to $\left.40^{\circ} \mathrm{N}\right)$, in modifying the thermal forcing $\left(5^{\circ} \mathrm{C}\right.$ warming from May to July). They showed that such a warming moistens the lower layers of the Sahara through advection and reduces the thermal gradient between the Saharan heat low and the Mediterranean, tending to decrease the NE winds (Harmattan). Finally using observations and reanalyses over multi decadal periods, Joly (2008) provided evidence of a significant intensification of the Mediterranean/West African relationship in last years.

However, up to date, there are some intriguing results regarding the thermal forcing of the Mediterranean Sea into the West African monsoon (WAM) system. For instance, Rowell (2003) and Jung et al. (2003) described similar outcomes though using different SST patterns, prescribing thermal anomalies in the eastern and western Mediterranean basins respectively. There are also puzzling features concerning the atmospheric response related to Sahel precipitation, as local circulation anomalies (Raicich et al. 2003; Peyrillé et al. 2007) or 3-D evidences for mechanisms favoring the northward migration of the monsoonal rainbelt (Peyrillé et al. 2007; Peyrillé and Lafore 2007). Indeed these empirical and numerical studies are either cases studies focusing on specific processes (i.e., Peyrillé et al. 2007), or analyzes taking into account the climatic transition which affected West Africa during the second par of the XXth century, i.e., the existence of a succession of anomalously wet years in the 50 and $60 \mathrm{~s}$ followed by abnormally dry years in the 70 and $80 \mathrm{~s}$ as in Rowell (2003). So the purpose of this study is not to reproduce and discuss previous results for resolving the questions above, but to reexamine the relationship through both historical data covering a period which does not include the negative tendency in West African precipitation between the 50 and $90 \mathrm{~s}$, and a lot of dedicated numerical GCM experiments.

This article focuses on the relationship between surface Mediterranean temperatures and the West African monsoon using Satellite observations and atmospheric reanalyses over the period 1979-2006 along with control and sensitivity experiments performed on 4 GCMs with an ensemble approach. The following section presents briefly the data used while Sect. 3 portrays the basic features of the Mediterranean/African linear relationship through different SVD analyses of the temperature and outgoing longwave radiation (OLR) fields and correlations with observed precipitation. Section 4 focuses on the observed contrasted impacts in Warm and Cold situations over the western and eastern Mediterranean basins to analyze both the linearity of the connection with the OLR signal and its impacts on observed atmospheric dynamics and Hadley circulation. In Sect. 5, we will present different sensitivity experiments relative to the Mediterranean thermal variability performed on four climate models before analyzing the results in terms of rainfall impacts and atmospheric dynamics though an ensemble approach. Section 6 will propose a short discussion before the conclusion.

\section{Selected historical datasets}

Land-based precipitation data (stations) do not allow accurate description of the West African rainfall variability at short time scales (i.e., lower than 1 month), especially in the recent years. This is mainly due to the anisotropy of the network, the number of stations documenting correctly rain falls being too low, especially along the meridional plane. For example the global surface summary of day dataset (GSOD) exhibits large areas without any station in the Benin, Togo and Burkina Faso positioned over the central parts of West Africa. Moreover some daily values are either not reported, or very underestimated or false which changes the coverage with days, months and years. After the year 2000 the series are too incomplete for analysing accurately the daily or 5-day fields.

So for describing the monthly and seasonal time scales, we selected first the monthly precipitation from the high-resolution gridded CRU TS 2.1 data-set. These files comprise 1224 grids of observed climate, for the period 1901-2002, and cover the global land surface at 0.5 degree resolution (see New et al. 2002; Mitchell et al. 2004). For shorter time scales, rainfall information has been selected from the CPC Merged Analysis of Precipitation (CMAP, Xie and Arkin 1997) and from the Global Precipitation Climatology Project (GPCP, Adler et al. 2003; Xie et al. 2003) estimates on a $2.5 \times 2.5$ degree latitude/longitude grid at a 5-day time-scale over the period 1979-2006. 
These satellite-derived estimates do not describe exactly the real world but have many advantages over current in situ data: they are coherent in space and time at 5-day scale, they have been often described and used and they give access to different information. However in northern summer, the mean precipitation differences (CMAPGPCP) are positive over land and negative over Ocean with a typical difference of $\pm 0.1 \mathrm{~mm} /$ day (Gruber et al. 2000). This could be due to the fact that, by contrast with GPCP, CMAP uses uncorrected rain gauge over land (Gruber et al. 2000). Moreover, Yin et al. (2004) indicate that (1) the GPCP/CMAP spatial correlation is higher over land than over ocean; (2) in general precipitation over ocean represented by the GPCP is more accurate while over land the two products are close. More details can be found in Louvet et al. (2007).

The Sea Surface Temperatures provide from the most current version of the Kaplan dataset produced by taking the MOHSST5 version of the GOSTA data set from the U.K. MET office and using EOF projection, optimal interpolation, Kalman Filter analysis, and an optimal smoother for filling in any missing data. The data set is stored on a $5^{\circ} \times 5^{\circ}$ grid.

Skin temperatures and atmospheric data in all the troposphere provide from National Centers for Environmental Prediction (NCEP) and is called NCEP/DOE AMIP-II Reanalysis (R-2) over the period 1979-2006. This dataset can be hence considered as a mix of in situ and satellite observations and modelling. It improves however upon the NCEP/NCAR Reanalysis (R-1) by fixing the errors and by updating the parameterizations of the physical processes. It has been also extensively used and described (Kanamitsu et al. 2002; Maurer et al. 2001 among others). To be very concise one can say that $\mathrm{R}-2$ provides more accurate pictures of soil wetness, near surface temperature and surface hydrology budget over land, and radiation fluxes over Ocean. The new boundary layer and convection schemes have also modified the water vapor profile: R-2 has more moisture in low levels than R-1.

The daily NOAA Interpolated Outgoing Longwave Radiation (OLR) data are used in a $2.5^{\circ} \times 2.5^{\circ}$ version where all gaps have been filled with temporal and spatial interpolation as described in Liebmann and Smith (1996). OLR is an interesting additional dataset for our purpose since it measures the direct emission from the surfaces (Earth, clouds). It allows therefore clear depiction between clear-sky regions which concentrate the highest OLR values from the warmest surfaces and deep convective regions where the highest and coldest clouds (cirrus and tops of cumulonimbus) dominate. However OLR values in $\mathrm{W} / \mathrm{m} 2$ are not direct measurements of deep convection since for example in clear-sky situations, OLR measures the direct emission from the warmer land or oceanic surfaces.

\section{Basic features of the Mediterranean/African relationship}

The relationship is here examined through several spatial indices and objective field analyses using SSTs, skin temperatures, precipitation and OLR.

\subsection{Composite and correlation analyses through observed precipitation}

This section illustrates the basic relationship observed at monthly scale using selected spatial indices describing North African rainfall and the Western and Eastern Mediterranean surface temperatures over the recent period 1979-2002. Table 1 presents first the rainfall means in $\mathrm{mm}$ observed in North Africa $\left(5-20^{\circ} \mathrm{N}\right)$ and in the Sahelian belt $\left(13-18^{\circ} \mathrm{N}\right)$ for both the boreal summer (JAS) and the months from May to October. The Warm minus Cold $(\mathrm{W}-\mathrm{C}$ ) differences (see the legend of Table 1 for more details) are displayed in lines 3 and 4. Two important points emerge: (1) in boreal summer the warmest situations in the Mediterranean are associated with rainfall excess over North Africa and the Sahel and are preceded by rainfall deficits in spring; (2) this relationship seems to reinforce when the Eastern Mediterranean and the Sahel band are considered although only the North African index in September can be considered as significantly different.

Table 2 allows us give more details regarding the relative weight of long-term ( $>8$ years) and inter-annual ( $<8$ years) variability in different July-September spatial indexes describing skin temperatures over the West and East Mediterranean, and the GPCP and CMAP rainfall estimates averaged over central Sudan $\left(9-13^{\circ} \mathrm{N}\right)$ and the western $\left(17-10^{\circ} \mathrm{W}\right)$, central $\left(10^{\circ} \mathrm{W}-10^{\circ} \mathrm{E}\right)$ and eastern $(10$ $20^{\circ}$ E) Sahel $\left(13-18^{\circ} \mathrm{N}\right)$. Several important points can be mentioned. First the strongest significant correlations are generally registered with the GPCP estimates. Second the relationship between Sahelian rainfall and the Mediterranean thermal variability is significantly stronger when thermal variances $<8$ years are considered, above all in CMAP estimates. Thirdly the mean correlation between skin temperatures in the 2 basins and the Sudan-Sahel rainfall equals +0.31 ( $9 \%$ of variance, not significant taking into account autocorrelation in the series) with unfiltered series but increases to +0.49 (24\% significant at $p=0.05$ ) when variability lower than 8 year is taken into consideration. Although the difference between these values is not very large, this is rather different from Rowell (2003) who, given the period analyzed (1946-1996), took mainly into consideration the long-term negative trend in West African rainfall: $r=+0.61$ for variability $>8$ year and +0.31 for $<8$ year. Notice also that thermal variability in the Eastern Mediterranean explains in mean 20\% of the 
Table 1 Observed relationship between Mediterranean surface temperatures and North African $\left(5-20^{\circ} \mathrm{N}\right)$ and Sahel $\left(13-18^{\circ} \mathrm{N}\right)$ rainfall amounts averaged between $15^{\circ} \mathrm{W}$ and $30^{\circ} \mathrm{E}$ for the seasons July-September (JAS) and the months May-October

\begin{tabular}{|c|c|c|c|c|c|c|c|}
\hline $15^{\circ} \mathrm{W}-30^{\circ} \mathrm{E}$ & JAS & M & $\mathrm{J}$ & $\mathrm{J}$ & A & $\mathrm{S}$ & $\mathrm{O}$ \\
\hline \multicolumn{8}{|l|}{ North Africa: $05-20^{\circ} \mathrm{N}$} \\
\hline Mean rainfall amounts $(\mathrm{mm})$ & 410 & 66 & 95 & 136 & 159 & $\underline{115}$ & 59 \\
\hline $\mathrm{W}-\mathrm{C}$ West Medit (\%) & +6 & -13 & -11 & -2 & $+15^{*}$ & \pm 4 & +15 \\
\hline $\mathrm{W}-\mathrm{C}$ East Medit (\%) & +11 & $-22 * *$ & -2 & +4 & $+13 \%$ & \pm 17 & +11 \\
\hline \multicolumn{8}{|l|}{ Sahelian belt: $13-18^{\circ} \mathrm{N}$} \\
\hline Mean rainfall amounts $(\mathrm{mm})$ & 219 & 8 & 27 & 73 & 101 & 44 & 8 \\
\hline W - C West Medit & +16 & -22 & -21 & +12 & +24 & +3 & +55 \\
\hline W - C East Medit & $+22 * *$ & $-44^{*}$ & +3 & $+18^{*}$ & +17 & $+39 * *$ & +44 \\
\hline
\end{tabular}

Mean rainfall amounts in $\mathrm{mm}$ and warm minus cold differences $(\mathrm{W}-\mathrm{C})$ in percentages relative to the western and eastern Mediterranean basins. Period 1979-2002. The warmest Mediterranean summers are 1987, 1989, 1990, 1991, 1994, 1999, for the Western basin and 1988, 1994, 1998, 2000, 2001, for the eastern basin The coldest ones are 1979, 1980, 1981, 1984, 1993, 1996, 1997, 2002 for the western basin and 1979, 1981, 1983, 1984, 1991, 1992, 1996, 1997 for the eastern basin. The significant values at $p=0.1(*)$ and $0.05(* *)$ using a Student $t$ test are indicated in italic and bold, respectively. Underlined values means that differences are significant with a null hypothesis that the East and West Mediterranean have the same relationship with rainfall'

Table 2 Correlation coefficients between July and September surface temperatures in the Western/Eastern Mediterranean and July-September CMAP and GPCP rainfall estimates averaged over western Sahel (WSAH), central Sahel (CSAH), Eastern Sahel (ESAH) and central Sudan (CSUD) with and without time filtering

\begin{tabular}{|c|c|c|c|c|c|c|c|c|}
\hline & \multicolumn{4}{|c|}{ Unfiltered series } & \multicolumn{4}{|c|}{ Filtered series: variability $<8$ years } \\
\hline & \multicolumn{2}{|c|}{ West Medit } & \multicolumn{2}{|c|}{ East Medit } & \multicolumn{2}{|c|}{ West Medit } & \multicolumn{2}{|c|}{ East Medit } \\
\hline & CMAP & GPCP & CMAP & GPCP & CMAP & GPCP & CMAP & GPCP \\
\hline WSAH & +07 & +38 & +15 & \pm 65 & +16 & +30 & +42 & +63 \\
\hline CSAH & +24 & +29 & +47 & \pm 57 & +41 & \pm 50 & \pm 65 & \pm 66 \\
\hline ESAH & +18 & +10 & +31 & +37 & \pm 52 & +44 & \pm 73 & \pm 66 \\
\hline CSUD & -13 & +42 & +01 & \pm 59 & +21 & +42 & \pm 58 & \pm 62 \\
\hline
\end{tabular}

The significant values at $p=0.1,0.05$ and 0.01 taking into account time autocorrelations in the series are indicated in italic, bold and underlined, respectively. Period 1979-2006

Sudan-Sahel rainfall total variance while the Western basin explains only $7 \%$.

\subsection{Robustness of the relationship}

The linear relationship is further analysed by computing several Singular Value decompositions (SVD) between temperature fields and OLR fields over the period 19792005. Interpolated OLR data are a practical estimate of convective activity over West Africa, since OLR values $<240 \mathrm{~W} / \mathrm{m}^{2}$ depict the occurrence of high clouds closely linked to deep moist convective areas as those which are positioned within ITCZ. These SVDs have been performed both at monthly, 5-day and daily scales in isolation to be not confounded with longer-term variations and using different time filters. The main results are reported in Figs. 1 and 2 and Table 3.
Figure 1 refers to a synchronous (no lag) analysis performed between monthly skin temperatures observed over an extended Mediterranean region $\left(5^{\circ} \mathrm{W}-40^{\circ} \mathrm{E} ; 20-45^{\circ} \mathrm{N}\right)$ and monthly OLR values referring to an extended WAM region $\left(20^{\circ} \mathrm{W}-40^{\circ} \mathrm{E} ; 10^{\circ} \mathrm{S}-20^{\circ} \mathrm{N}\right)$. The total covariance equals $32.7 \%$ of the total variance and the squared covariance fractions of the two leading modes match 33.4 and $22.5 \%$ respectively. The first heterogeneous mode and its related time coefficients are displayed in Fig. 1a, b. They clearly attest the statistical linkage between warm anomalies restricted to Eastern Mediterranean and low OLR anomalies expanding along $10-15^{\circ} \mathrm{N}$ and eastward to about $10^{\circ} \mathrm{W}$. As noticed above, the Eastern Mediterranean concentrates the highest positive loadings, while the western basin and continental regions somewhat northward to the mean ITCZ position accumulates the strongest negative loadings (meaning enhanced deep convection) with the 
Fig. 1 First and second leading July-September SVD modes performed between skin temperatures in the

Mediterranean region and West African OLR values at monthly time step: a, b $(\mathbf{d}, \mathbf{e})$ describe the first (second) mode in terms of heterogeneous field of covariability and expansion time coefficients while (c) displays lead/lag correlation coefficients between a spatial index averaging surface temperatures in the Mediterranean basin $\left(32-40^{\circ} \mathrm{N}\right.$; $\left.6-36^{\circ} \mathrm{W}\right)$ and OLR values in the Sahel zone $\left(10-20^{\circ} \mathrm{N} ; 15^{\circ} \mathrm{W}-\right.$ $\left.30^{\circ} \mathrm{E}\right)$. Values significant at $p=0.05$ taking into account autocorrelations in the series are marked by asters. Period JulySeptember 1979-2006

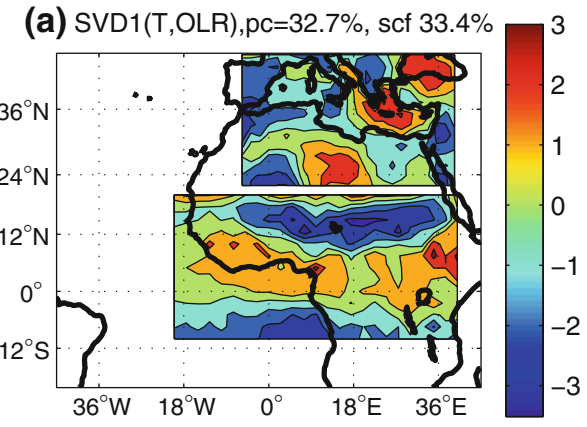

(b) SVD1 (detrend), $r=+0.70$

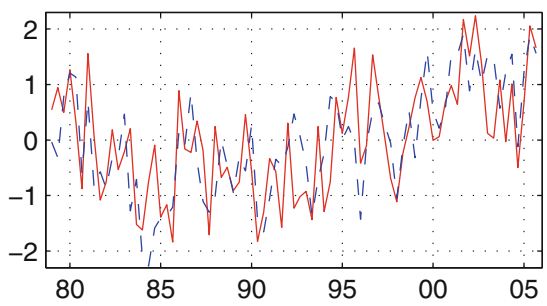

(c) Lead/lag CC(Med,OLR)

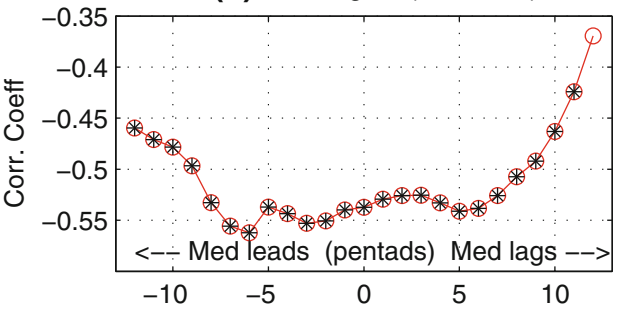

(e) SVD2(detrend),r=+0.61

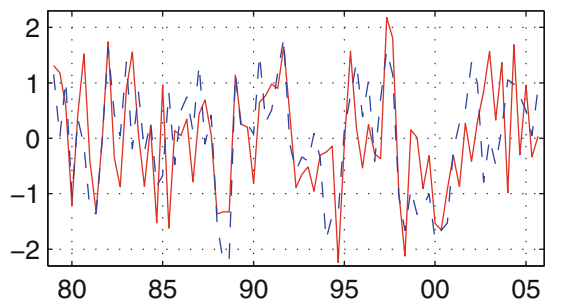

maximum located in the central and eastern Sahel. Such a result agrees well with those shown by Polo et al. (2008) at monthly-interannual scale, suggesting an active role of the eastern Mediterranean SST into the Sahelian variability. In fact, the coupled OLR and temperature time series in Fig. 1b are largely correlated $(r=+0.70$, significant at $p=0.01$ taking into account autocorrelation in the series); they display both an in-phase interannual signal and the recent rainfall recovering since the $90 \mathrm{~s}$. When these coefficients are averaged over the successive JAS season its correlation increases to +0.87 , while the temperature and OLR time series are positively correlated with JAS rainfall averaged over central $\left(10^{\circ} \mathrm{W}-10^{\circ} \mathrm{E}\right)$ Sahel: +0.50 and +0.67 , significant at $p=0.05$ and $p=0.01$ respectively, taking into account autocorrelation in the series.

By construction the second skin temperature-OLR mode (Fig. 1c, d) is less energetic and registers lower serial correlation between time series $(r=+0.61$, significant at $p=0.01$ taking into account autocorrelation in the series). However it is the direct complement of the first one: the strongest (positive) temperature loadings are here restricted to the West Mediterranean. A surface warming in this region is linked to lower OLR values (deeper convection) extending both in the Western parts of the Sahel (Senegal, Mali) and over equatorial eastern Atlantic (Gulf of
Guinea). When time coefficients are averaged over the JAS seasons the correlation increase to $+0.70(p=0.01)$, and the temperature and OLR time series are positively correlated with JAS rainfall over the western parts $\left(18-10^{\circ} \mathrm{W}\right)$ of the Sahel: +0.31 and +0.43 respectively, this last value being significant at $p=0.05$.

In fact the Mediterranean/WAM relationship is not purely synchronous as illustrated in Fig. 1c. This diagram displays the lead/lag correlation coefficients computed between spatial indexes averaging OLR values in the Sahel zone $\left(10-20^{\circ} \mathrm{N} ; 15^{\circ} \mathrm{W}-30^{\circ} \mathrm{E}\right)$ in JAS, at the heart of the rainy season and 3-month surface temperatures in the whole Mediterranean basin $\left(32-40^{\circ} \mathrm{N} ; 6-36^{\circ} \mathrm{W}\right)$ moving with a 5-day (pentad) time-step before and after JAS. Near all the values are significant at $p=0.05$ but the strongest correlation is registered when the Mediterranean temperatures are leading OLR by 6 pentads ( 1 month).

\subsection{Evolution of the leading skin temperature/OLR mode at the monthly scale}

In order to assess better the robustness of the Mediterranean/ WAM lagged relationship, Fig. 2 refers to SVD analyses performed at the monthly scale between Mediterranean skin temperatures and WAM OLR values 1 month later referring to the same domain that in Fig. 1. Here linear trends in the 
(a) $36.9 \%$, May-> Jun

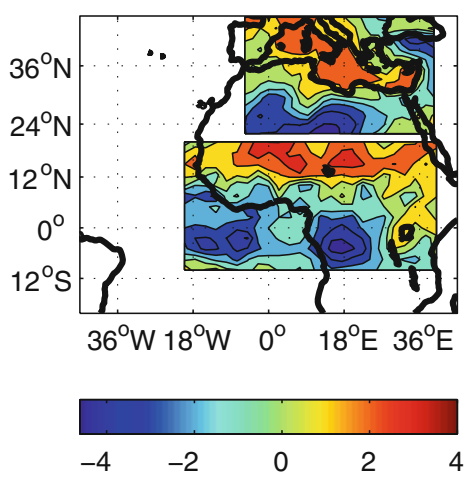

(d) $39.4 \%$, Aug->Sep

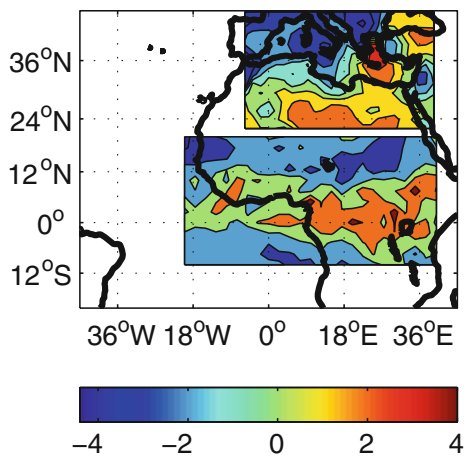

(b) $37.4 \%$, Jun-> Jul
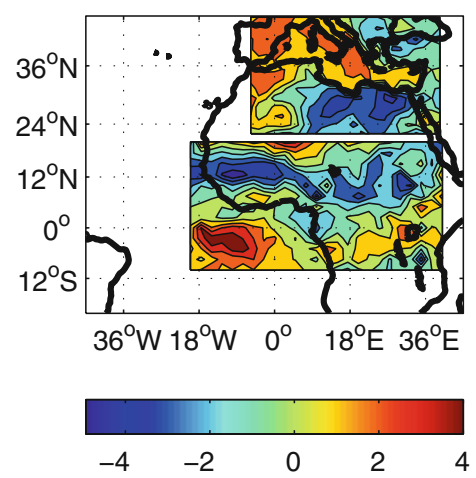

(e) $38.2 \%$, Sep->Oct

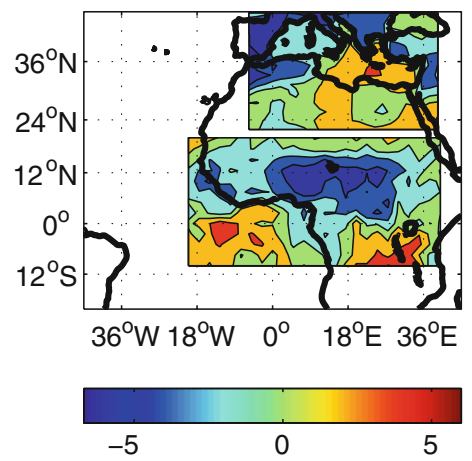

(c) $36.8 \%$, Jul->Aug
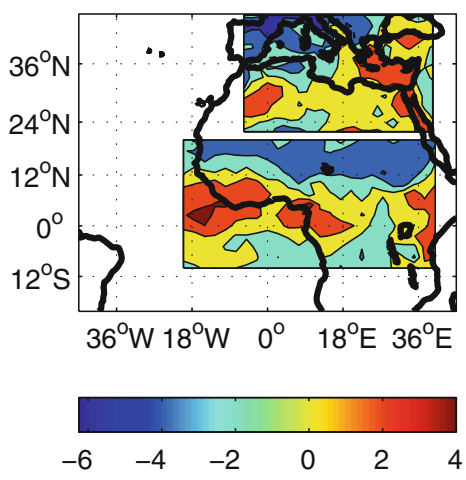

(f) $39.5 \%$, Oct->Nov

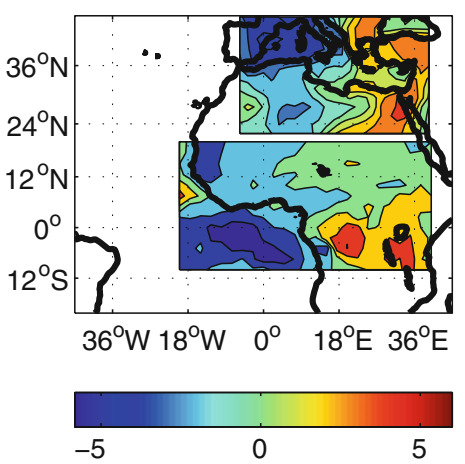

Fig. 2 Monthly evolution of the 1st SVD heterogeneous mode between skin temperature in the Mediterranean region and one-month lagged WAM OLR anomalies; spatial domains as in Fig. 1. The respective covariance fractions in \% of total variance are indicated. Period 1979-2006

Table 3 Percentages of covariance and covariance fractions explained by the leading July-September mode (SVD1) at a daily timescale and time correlations (Corr SVD1) with and without linear trend (detrend) and as a function of time filtering in different ranges for capturing the 3-5 days (AEWs), < 10-day (synoptic), 10-90 days (intraseasonal) variability over the period 1979-2006

\begin{tabular}{llllll}
\hline $\begin{array}{l}\text { T, OLR, } \\
\text { days }\end{array}$ & $\begin{array}{l}\text { With } \\
\text { trend }\end{array}$ & Detrended & 3-5 days & $<10$ days & 10-90 days \\
\hline \% cov/var & $\mathbf{1 1 . 5}$ & 17 & 10.7 & 8.5 & 9.9 \\
\% SVD1 & $\mathbf{5 1 . 9}$ & 29 & 46.2 & 45.6 & 43.9 \\
Corr SVD1 & $\mathbf{+ 5 1}$ & +42 & +48 & +41 & +26 \\
\hline
\end{tabular}

series have been removed and the display focuses on the May/June to October/November evolution of the lagged temperature/OLR relationship. The results confirm first the statistical linkage between the East Mediterranean and WAM domains shown above (Fig. 1a). Second they show that there is no negative OLR anomaly over the Sahel before June/July (Fig. 2b), confirming the previous dry regime as indicated from Table 1 (in May/June; Fig. 2a). There, warm anomalies are associated with positive values of OLR over Sudan-Sahel, meaning decreased convection. From Jul/Aug to Oct/Nov temperature loadings reinforce on the eastern Mediterranean according to the leading monthly coupled mode (Fig. 1a), while OLR anomalies are related to increased deep motions (Fig. 2c-f).

Once again, the East Mediterranean concentrates the highest positive temperature loadings in connection with WAM deep convection, which points out largest anomalies along $10-15^{\circ} \mathrm{N}$ and mainly located over inland regions. Also at daily scales, Table 3 summarizes the percentages explained by each leading JAS-mode, time correlation between time series before and after removing all linear trends at each grid point (columns 1-2). In fact the field coupling is slightly lower when the series are detrended with a leading mode, spatially similar to Fig. 2a but less energetic ( 29 vs. $52 \%$ of squared covariance fraction) and positively correlated $(+0.42$ vs. +0.51$)$. Other columns underline possible connections with oscillatory modes at synoptic scale ( $<10$ days) such as African Easterly Waves (AEW) in the 3-5 day range, when longer-term mean coefficients are removed.

To test the linearity of the connection the next section contrasts the signals observed in warm and cold situations over the Western and Eastern Mediterranean. 


\section{Contrasted impacts in warm and cold situations}

\subsection{OLR signal}

The mean July-September OLR field displayed in Fig. 3a exhibits high OLR values in the Mediterranean region and low OLR values near the ITCZ mean location since in dry subtropics (no cloud), OLR depends mainly on surface temperatures and is generally greater than $260 \mathrm{~W} / \mathrm{m}^{2}$ : any surface warming (cooling) in the lowest levels of the troposphere over the Mediterranean tends to enhance (reduce) OLR values. By contrast, in the vicinity of the ITCZ which concentrates the lowest OLR values $\left(<240 \mathrm{~W} / \mathrm{m}^{2}\right.$ in Fig. 3a) OLR is directly linked to the altitude of clouds (convective towers).

The warm (cold) composites relative to the Western and Eastern Mediterranean are shown in Fig. 3b, c, respectively (Fig. 3d, e). They contrast the 8 warmest and the 8 coldest seasons versus all the remainders (caption in Fig. 3 indicates the selected years). Once again the signal is more significant in Fig. 3c and e, i.e. when the possible thermal forcing involves the East Mediterranean: warm (cold) anomalies in the Eastern basin are associated with lower (higher) OLR values. This denotes an enhancement (a reduction) of deep convection in the monsoon region when the East basin is abnormally warm (cold) and suggests hence the existence of associated signals in atmospheric dynamics.

\subsection{Atmospheric dynamics}

Vertical cross sections of wind and specific humidity along the $20^{\circ}-0^{\circ} \mathrm{W}$ and $0^{\circ}-30^{\circ} \mathrm{E}$ meridional planes and relative to the West and East Mediterranean are presented in Fig. 4. Panels a, b show the mean location and intensity of cell circulations along with the regions where specific humidity exceeds $10 \mathrm{~g} / \mathrm{kg}$. The northern and southern overturning cells are easily recognizable between the humid Mediterranean and monsoon regions (shading). The southern cell, where the monsoon takes place, includes southerly/northerly horizontal branches in low/high levels and ascending/ subsiding branches located respectively by $8-10^{\circ} \mathrm{N}$ and $20^{\circ} \mathrm{S}$. Westward to the $0^{\circ}$ meridian the strong ascents are associated with strong northerlies at $200 \mathrm{hPa}$ southward to
Fig. 3 Warm and cold composites of OLR fields in July-September: (a) mean field; (b) and (c) differences between the warmest situations and all the others relative to the Western and Eastern Mediterranean, respectively; (d) and (e) as above but for the coldest situations. The warmest JAS seasons are 1987, 1989, 1990, 1991, 1994, 1999, 2003, 2006 for the Western basin and 1988, 1994, 1998, 2000, 2001, 2003, 2005, 2006 for the eastern basin. The coldest ones are 1979, 1980, 1981, 1984, 1993, 1996, 1997, 2002 for the western basin and 1979, 1981, 1983, 1984, 1991, 1992, 1996, 1997 for the eastern basin. The shadings refer to OLR values $<240 \mathrm{~W} / \mathrm{m}^{2}$ with a $5 \mathrm{~W} / \mathrm{m}^{2}$ increment (in a) and to the significant signals at $p=0.1$ using a Student $t$ test (in $\mathbf{b}-\mathbf{e}$ ). Period 1979-2006 (a) OLR in JAS

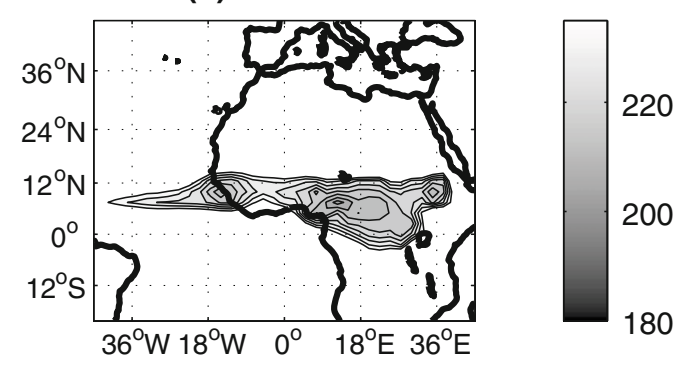

(b) Warm(West) OLR in JAS

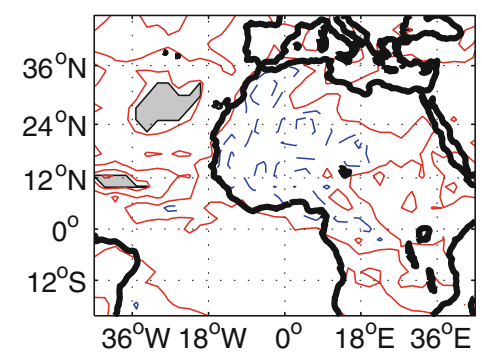

(d) Cold(West) OLR in JAS

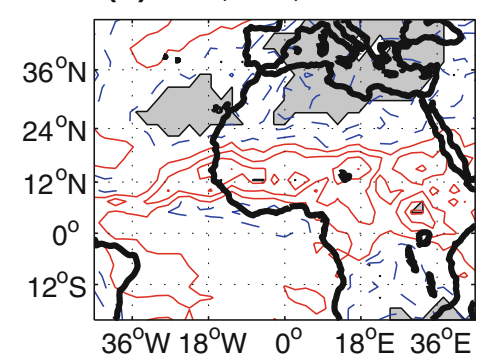

(c) Warm(East) OLR in JAS

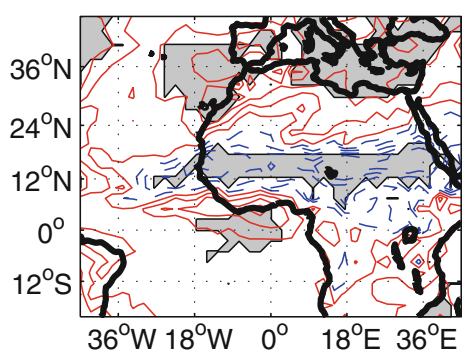

(e) Cold(East) OLR in JAS

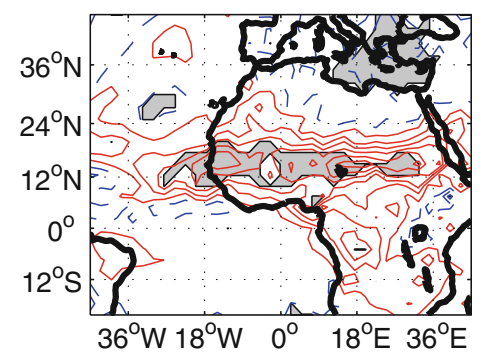


Fig. 4 July-September mean meridional/vertical cross sections and composites of wind and specific humidity along the $20^{\circ}-0^{\circ} \mathrm{W}($ left $)$ and $0^{\circ}-30^{\circ} \mathrm{E}$ (right) meridional planes: (a) and (b): mean circulation; $(\mathbf{c}, \mathbf{d})$ warm composites relative to the Western Mediterranean; (e, f) warm composites relative to the Eastern Mediterranean. In (a, b) the shadings points to the layer where specific humidity $>10 \mathrm{~g} /$ $\mathrm{kg}$; in (c-f), red arrows and shadings refer to the significant signals in wind and specific humidity at $p=0.1$, respectively, after using a Student $t$ test. Period 1979-2006 (a) Cross section: $20 \mathrm{~W}-0$

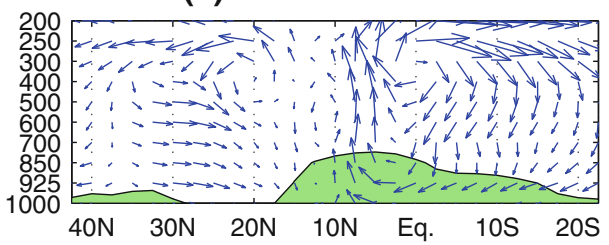

(c) West Med composite: $20 \mathrm{~W}-0$

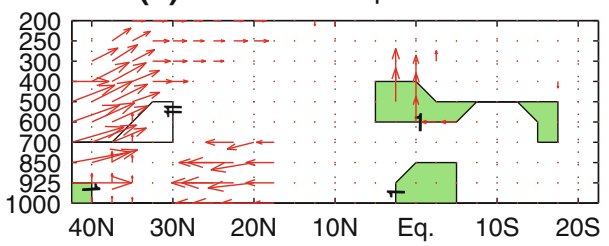

(e) East Med composite: 20W-0

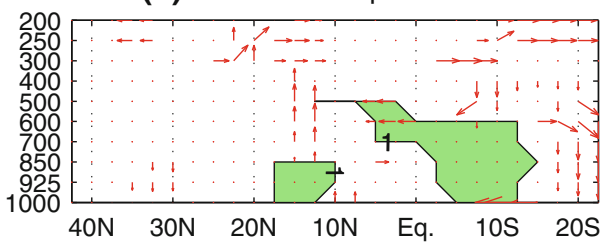

(b) Cross section: 0-30E

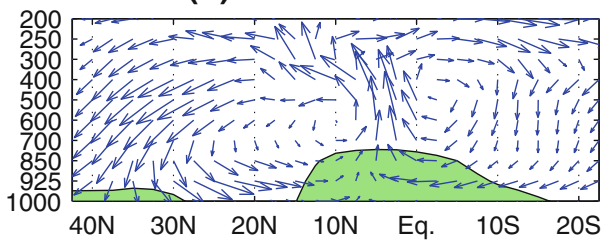

(d) West Med composite: 0-30E

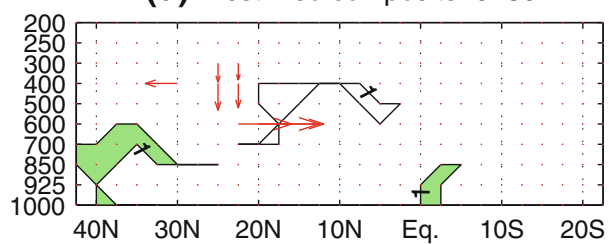

(f) East Med composite: 0-30E

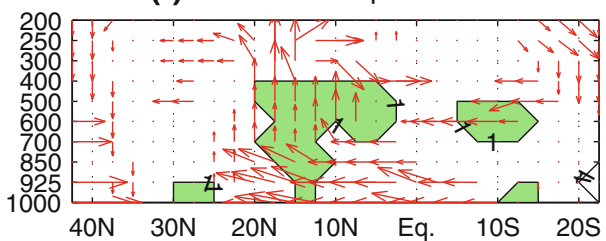

the equator (Fig. 4a) which tends to fuel monsoon overturning in the southern cell. By contrast eastward to the $0^{\circ}$ meridian the ascents fuel preferentially the northerlies in low levels from the Eastern basin and hence the northern cell (Fig. 4b).

Warm composites in Fig. 4c-f exhibit significant signals in both meridional circulation and specific humidity especially. Warm conditions in the Western basin are associated, westward to $0^{\circ}$, with lower-levels convergence and upperlevels ascending motions in the northern subtropical latitudes, and with significant moisture increase (shadings in Fig. 4c) in the low and mid troposphere above the equatorial Atlantic. However only $3 \%$ of the area can be considered as significant and there is no clear meridional-connection between the former and the latter. Neither a clear signal appears eastward to $0^{\circ}$. By contrast warm conditions in the Eastern basin reinforce the southern (monsoon) cell circulation between $0^{\circ}$ and $30^{\circ} \mathrm{E}$ (Fig. 4f) with $5 \%$ of global field significance): low level advections from the South in temperature and moisture are significantly enhanced, while air ascents within the ITCZ and air descents above the Southern Tropics strengthen. This is accompanied by a significant moisture increase (shading in Fig. 4f) under $400 \mathrm{hPa}$ over the continent $\left(5-20^{\circ} \mathrm{N}\right)$. To a lesser extent, but of equal statistical significance, the northern Hadley cell is also reinforced showing a closed circulation.

The results reported in Sects. 3 and 4 are thus compatible with the existence of a significant statistical relationship between the East Mediterranean and the WAM-Sahel region. In order to check whether this is interpretable in terms of Mediterranean forcing, we will analyze multimodel outputs using SST sensitivity experiments performed on 4 AGCMs. This approach allows production of more reliable climate features than a single model method since climate simulations performed on any given model are sensitive to systematic errors, as previously shown by, among others, Bader and Latif (2003) and Giannini et al. (2003).

\section{Numerical study}

\subsection{Description of the sensitivity experiments}

Several SST sensitivity experiments linked to normal, warm and cold situations over the Mediterranean have been performed on four AGCMs:

- ARPEGE-Climat Version 3 IPCC-AR4 in truncature 42 with 45 levels run at CNRM (Centre National de Recherches Météorologiques, Météo-France)

- ECHAM Version 4 in truncature 30 with 32 levels run at ENEA (Italian National Agency for New Technologies, Energy and Environment)

- LMDZ Version 4 (96 long, 71 lat and 19 levels) run at IPSL (Institut Paul-Simon Laplace)

- UCLA Version $7.3\left(2^{\circ}\right.$ long $\times 2.5^{\circ}$ lat, 29 levels $)$ run at UCM (Universidad Complutense de Madrid)

In these experiments the SST anomaly patterns were calculated from observed ERSST dataset (Smith and 
Reynolds 2004) and over the period 1979-2005. The African monsoon multidisciplinary analyses (AMMA) community decided that the boundary conditions were based on the expansion coefficient of the leading Extended Maximum Covariance mode between WAM-precipitation (CMAP dataset) and Mediterranean-SST described in Polo et al. (2008). This mode shows strong positive links between the Sahelian rainfall and the spring to summer evolution of the SST anomalies in the eastern Mediterranean. In order to introduce some physical considerations in the SST patterns definitions, a SST composite was constructed by averaging years for which the phasing between SST and African precipitation was maximal. They have been computed chosen those years in which the SST and June-September precipitation expansion coefficients were higher than 1 standard deviation (1984, 1987, 1991, 1992, 1997) and those in which the expansion coefficients were less that -1 standard deviation $(1979,1994,1999,2001)$. In order to amplify the SST signals, it has chosen to compute the difference between the positive-composite and the negative-composite of SST anomalies for defining the positive phase of the thermal forcing; while the negative phase was computed by multiplying the positive phase by -1 . The SST anomalous patterns were finally multiplied by two in order to amplify the atmospheric response (Fig. 5). SST conditions have then been prescribed with these anomaly patterns added to the climatology of observed global SST for the period 1979-2005.

The ENEA, IPSL and UCM institutions performed 10 simulations with different initial conditions for each experiment (cold, warm, and control with no superimposed SST anomaly) while CNRM performed 20 simulations, allowing available a total of 150 simulations. However to give each model the same weight, we will consider 10 simulations for each model and each experiment (control, cold and warm), hence $10 \times 4 \times 3=120$ simulations. Experiments have been run from 15th of April to 15th of October and each SST pattern have led to a set of 10 runs (20 runs for CNRM). Initial conditions have been taken from a long-term AMIP-type run with conditions representative of the end of the 20th century. A good way to do this was to take conditions around the 15th of April for 10 (or 20 for CNRM) different years in the set of possible initial conditions. The 10 (or 20) years for initial conditions have been taken from years 1979 to 1988 (or 1979-1998 for CNRM).

It is noteworthy that using such prescribed SST as a lower boundary condition implies that the sea acts as a reservoir of infinite heat capacity which is not the case in the real world where the Mediterranean has finite heat capacity. This tends to damp the surface heat fluxes and therefore to decrease the amplitude resulting from the model runs.

\subsection{Multi-model rainfall outputs}

In order to validate models outputs, Fig. 6 shows the May to September mean monthly rainfall fields averaged over the period 1979-2001 in the CPC merged precipitation and in the control experiments of each model. Nearly all models reproduce well seasonal evolution of the rainbelt both in terms of meridional displacements and of location of rainfall maxima (amounts $>6 \mathrm{~mm} /$ day are shaded). However systematic biases exist in each model. For example, the CNRM, IPSL and ENEA simulations tend to underestimate the rainfall amounts while UCLA overestimates. Notice also that the seasonal excursion of the (a) May

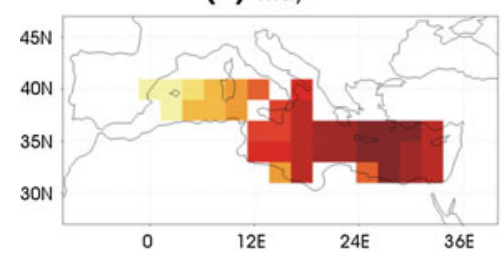

(d) Aug

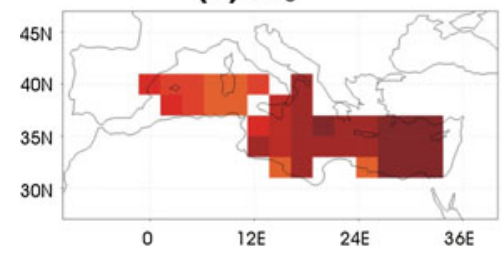

(b) Jun

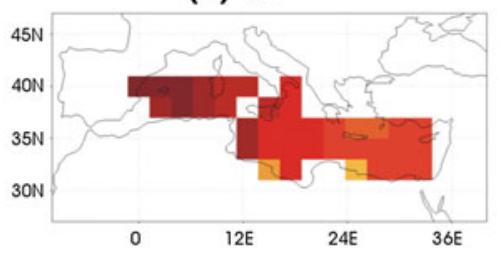

(e) Sep

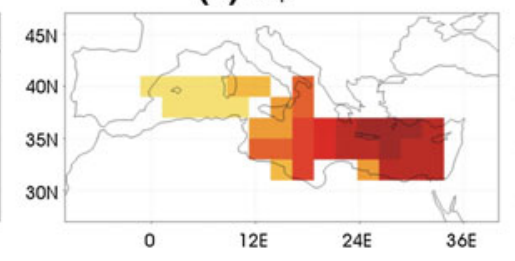

(c) Jul

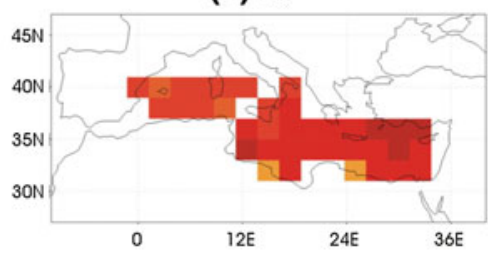

(f) Oct

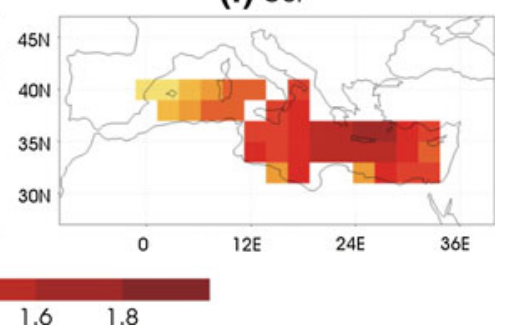

Fig. 5 May-October forcing fields used in the AGCM-sensitivity experiments. SST anomalies are expressed in ${ }^{\circ} \mathrm{C}$ units 
(a) Rainfall $M$

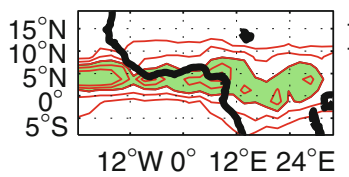

(f) CNRM M

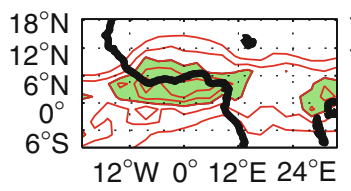

(k) ENEA M

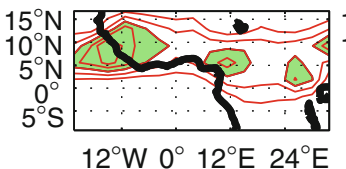

(p) IPSL M

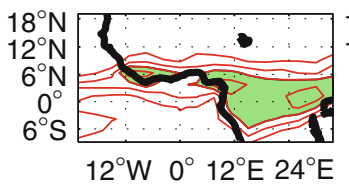

(u) UCLA M

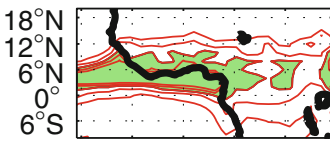

$24^{\circ} \mathrm{W} 12^{\circ} \mathrm{W} 0^{\circ} 12^{\circ} \mathrm{E} 24^{\circ} \mathrm{E}$ (b) Rainfall J

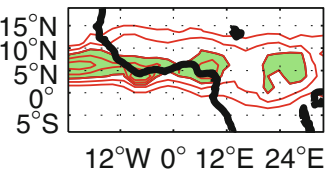

(g) CNRM J

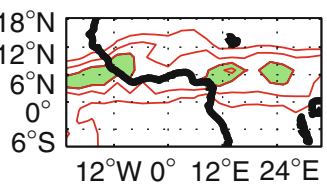

(I) ENEA J

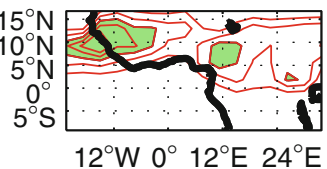

(q) IPSL J

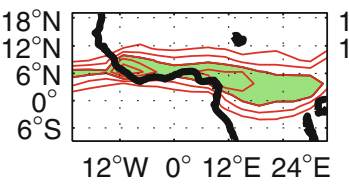

(v) UCLA J

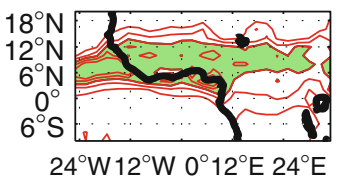

(c) Rainfall J

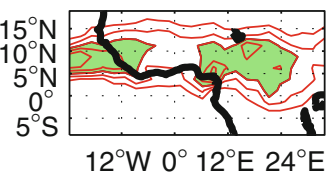

(h) CNRM J

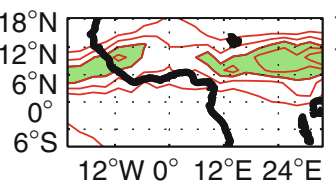

(m) ENEA J

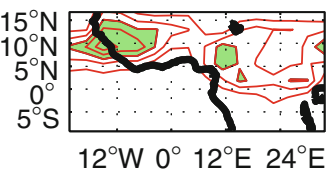

(r) IPSL J

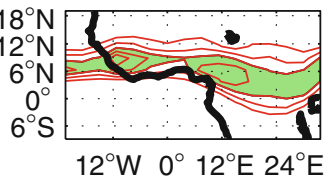

(w) UCLA J

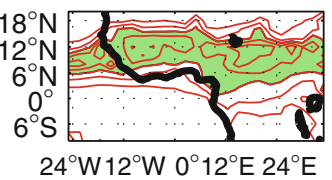

(d) Rainfall A

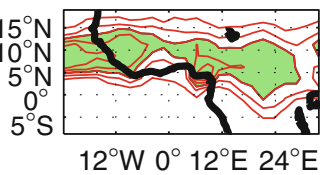

(i) CNRM A

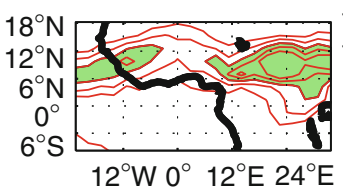

(n) ENEA A

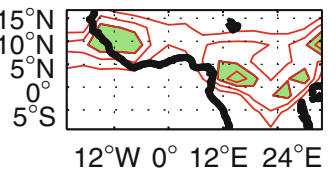

(s) IPSL A

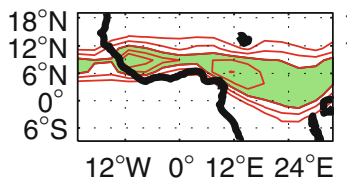

(x) UCLA A

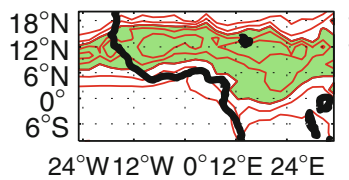

(e) Rainfall S

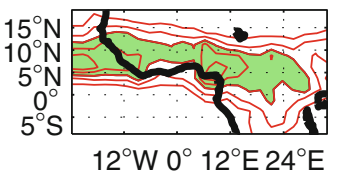

(j) CNRM S

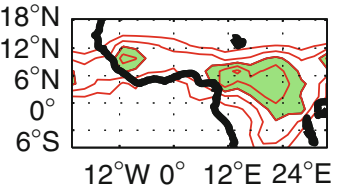

(o) ENEA S

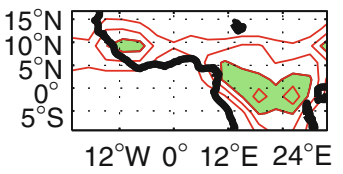

(t) IPSL S

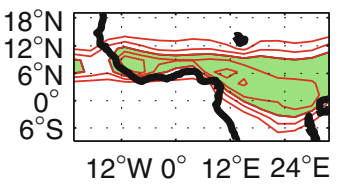

(y) UCLA S

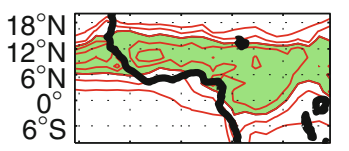

$24^{\circ} \mathrm{W} 12^{\circ} \mathrm{W} 0^{\circ} 12^{\circ} \mathrm{E} 24^{\circ} \mathrm{E}$
Fig. 6 May-September mean monthly rainfall fields from the CPC merged precipitation (a-e) on the period 1989-2001 and from the control experiments of each model CNRM (f-j), ENEA (k-0), IPSL (p-t) and UCLA (u-y). Isolines from 2 to $10 \mathrm{~mm} /$ day; shadings for values $>6 \mathrm{~mm} /$ day

conclusive at all, except with UCLA in Fig. 7o (6\%). In contrast, warm experiments produce significant Sahelian rainfall excesses in 3 out 4 models (CNRM, IPSL, UCLA with respectively 10,18 and $9 \%$ significant points), which outputs are in good agreement with our previous empirical results. The precipitation response from ENEA does not yield any significant anomaly, neither from C-CTL (Fig. 7g) nor from W-CTL (Fig. 7h). As shown in Fig. 6k-o, ENEA climatology is unable to simulate the latitudinal migration of the ITCZ-WAM system, and also fails in producing the maximum monsoonal rainfall, i.e. located in MJ instead of JAS (also in Losada et al. 2009, this issue). These features could largely explain the diffuse ENEA response; and, since this model does not reproduce the WAM seasonal cycle we will exclude its outputs in the following sections.

In Fig. 8 statistical distributions of the MJ and JAS rainfall outputs are displayed in standardized values both 
(a) $\mathrm{MJ}: \mathrm{C}-\mathrm{Ctl}(\mathrm{cnrm})$

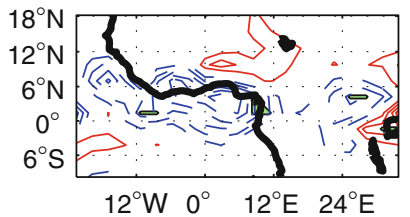

(e) $\mathrm{MJ}: \mathrm{C}-\mathrm{CtI}($ enea)

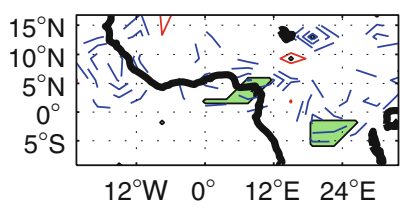

(i) MJ:C-Ctl(ipsl)

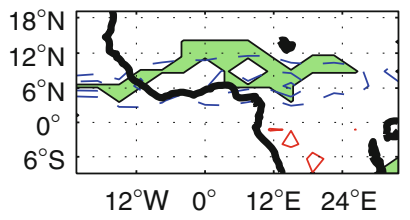

(m) MJ:C-CtI(ucla)

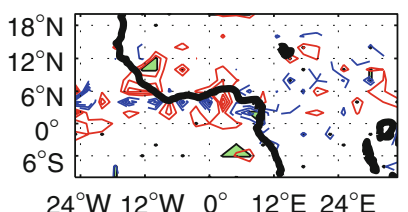

(b) $\mathrm{MJ}: \mathrm{W}-\mathrm{Ctl}(\mathrm{cnrm})$

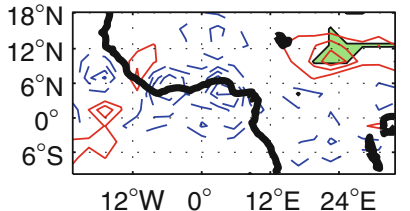

(f) MJ:W-CtI(enea)

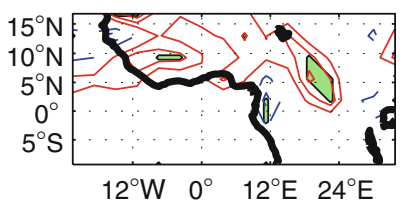

(j) MJ:W-Ctl(ipsl)

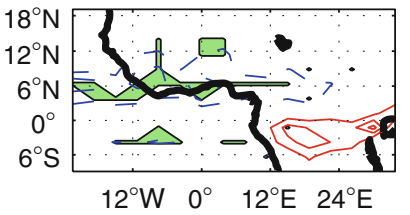

(n) MJ:W-CtI(ucla)

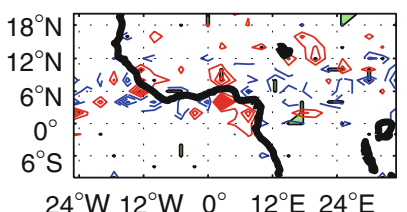

$24^{\circ} \mathrm{W} 12^{\circ} \mathrm{W} \quad 0^{\circ} 12^{\circ} \mathrm{E} 24^{\circ} \mathrm{E}$

Fig. 7 Cold minus Control and Warm minus Control rainfall differences in May-June (left part) and July-September (right part) for the different GCMs: red/blue curves for positive/negative

model by model (Fig. 8a, b), and for the mean-ensemble including all the models (Fig. 8c, d). In order to reduce the systematic errors due to each model, the biases have been considered separately for each model and anomalies with respect to the corresponding model climatology have been computed. The histograms refer to a classification in three categories illustrating the relative occurrences of below normal, quasi normal and above normal situations in warm and cold experiments (see the legend).

In MJ (Fig. 8a, c) there is no significant rainfall difference: no model causes a significant dispersion of the rainfall amounts produced by the cold and warm experiments (circles and asters in 8a, respectively). This is similar when using a model-ensemble approach: the histograms relative to the cold and warm simulations (white and blue bars in Fig. 8c, respectively) are alike. In JAS, at the opposite, the same experiments create contrasted responses, i.e., less (more) rainfall in cold (warm) situations. However, there is a more consistent signal in warm outputs than in cold ones: (1) the latter fail $32.5 \%$ in distinguishing

(c) JAS:C-Ctl(cnrm)

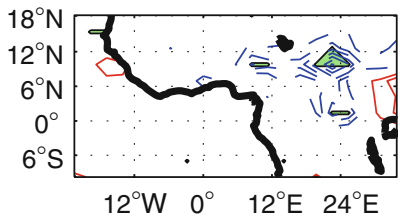

(g) JAS:C-Ctl(enea)

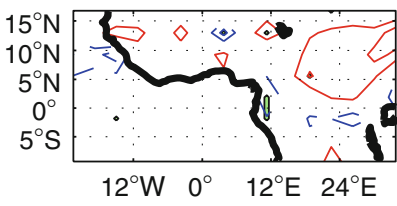

(k) JAS:C-Ctl(ipsl)

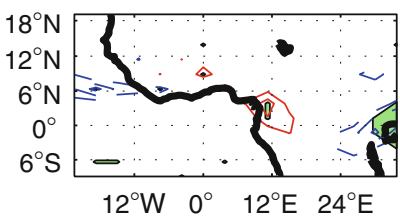

(o) JAS:C-CtI(ucla)

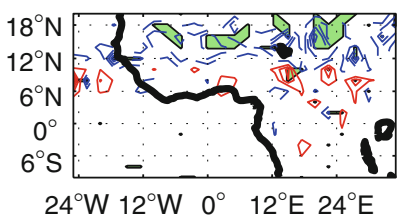

(d) JAS:W-CtI(cnrm)

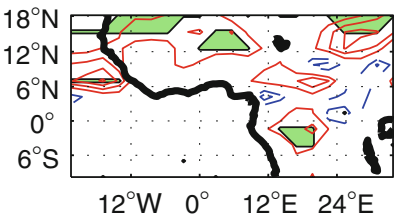

(h) JAS:W-CtI(enea)

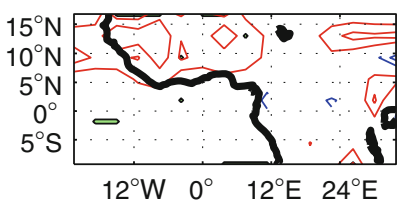

(I) JAS:W-Ctl(ipsl)

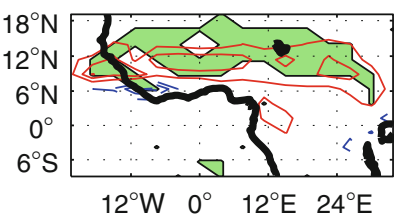

(p) JAS:W-CtI(ucla)

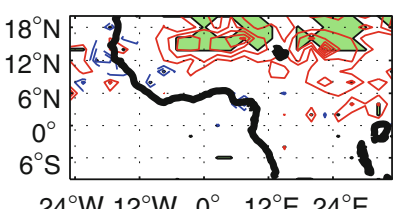

$24^{\circ} \mathrm{W} 12^{\circ} \mathrm{W} \quad 0^{\circ} \quad 12^{\circ} \mathrm{E} 24^{\circ} \mathrm{E}$

anomalies; shadings are superimposed when differences are significant at $p=0.05$ regarding a paired- $t$ test

the precipitation sign, against only $12.5 \%$ in the former (Fig. 8b); (2) and, considering 4-models together, the cold (warm) experiments model-ensemble generate a ratio of 9/18 (27/2) between excess/deficits (Fig. 8d). Warm situations in the Mediterranean seem therefore to impact more on West African precipitation in contrast with empirical findings, which showed a symmetrical signal (Fig. 3c, e). For all above, the rest of the work will focus on both the rainy season (JAS) and the forced-response in warm conditions.

\subsection{Large-scale wind circulation}

Multi-model composites using the anomaly method are now presented for contrasting respectively the 30 cold and 30 warm experiments to the 30 control runs in terms of circulation along the vertical meridional plane (CNRM, UCM, IPSL; excluding ENEA). Figure 9 presents vertical cross sections of wind components ( $\mathrm{u}, \mathrm{v}$, omega) as simulated by each model averaged along $20^{\circ} \mathrm{W}-30^{\circ} \mathrm{E}$ where 
Fig. 8 (Top) Simulated rainfall anomalies (vs control) of the West African Index $\left(20^{\circ} \mathrm{W}-\right.$ $30^{\circ} \mathrm{E} ; 5-20^{\circ} \mathrm{N}$ ) in standardized values for each GCM: MayJune (a) and July-September (b): circles and asters for cold and warm experiments. (Bottom) distributions into 3 classes of the model-ensemble responses relative to the cold and warm (thin bars) experiments : $1=$ deficits $(<-$ $0.5 \mathrm{std}), 2=$ normal and $3=\operatorname{excess}(>0.5 \mathrm{std})$ (a) Simulated rain anomalies in $\mathrm{MJ}$

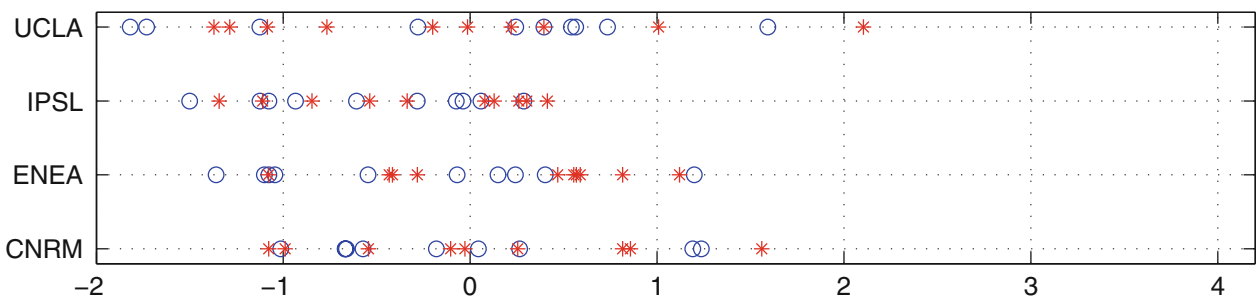

(b) Simulated rain anomalies in JAS

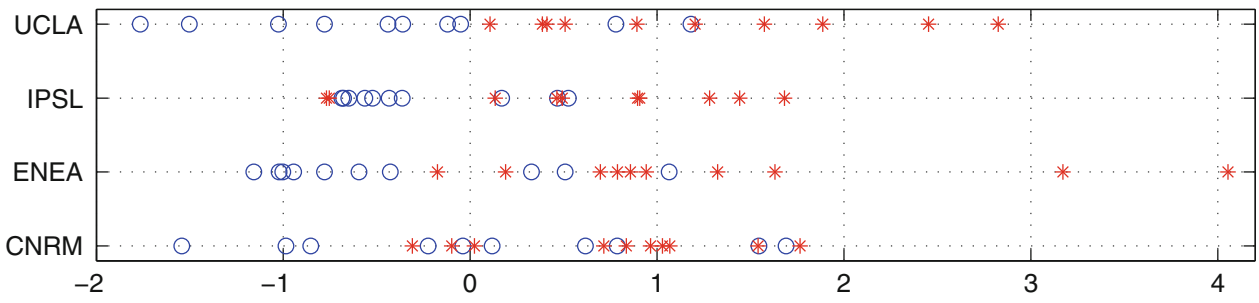

(c) MJ rains vs Cold and Warm

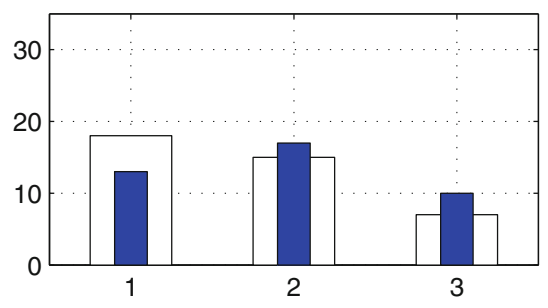

(d) JAS rains vs Cold and Warm

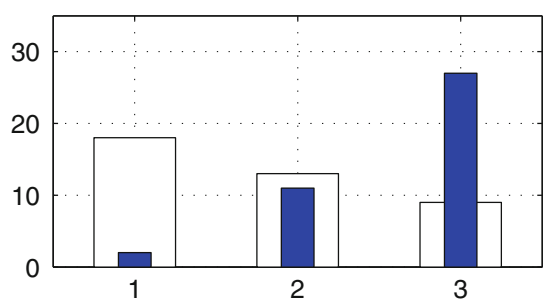

arrows refer to $\mathrm{v}$ and omega and contours to the zonal component: left panels display mean control simulations for each model while diagrams at right refer to the significant warm minus control differences tested with a Student $t$ test at $p=0.05$. Notice first that several basic elements of the mean monsoon circulation are well simulated by the GCMs (Fig. 9a, c, e), i.e., the monsoon cell southward to $20^{\circ} \mathrm{N}$ fuelled by air ascents over the Sahel domain and SW winds, the northern overturning circulation, the northern subtropical Westerly Jet in high troposphere and also subsidence over the northern subtropics. However there are some discrepancies with the easterly circulation. For example the African Easterly Jet (AEJ) in mid troposphere is strongly underestimated by UCM and CNRM while IPSL underestimates tropical easterly jet (TEJ) maxima in high levels.

Regarding to the W-CTL model responses, the more significant signals are observed in CNRM and UCM simulations (Fig. 9b, d); i.e., note the unclear circulation in IPSL run (Fig. 9f). As shown in observations (Sect. 4.2), it can be seen how CNRM experiment produces a significant reinforcement of both the northern and southern Hadley-cells; while UCM only yields the overturning anomaly of the southern meridional circulation.
These features reflect the enhancement of the ITCZ activity, according to one of the Rowell's (2003) feedback mechanism which involves reinforced monsoonal circulation (low-level westerlies and rising motion) responding to the enhanced moisture transport from the Mediterranean. An additional northward displacement of this deeper-ITCZ is also apparent: from 10 to $15^{\circ} \mathrm{N}$ in CTL to $15-20^{\circ} \mathrm{N}$ in $\mathrm{W}-\mathrm{CTL}$ (Fig. 9). In addition to strengthened southwesterly flow associated with increased latent heat (diabatic heating) in the Sahel region, forced by the above anomalous moisture convergence (Rowell 2003); Peyrillé et al. (2007), by using an idealized 2-D model, have suggested that the poleward extent of continental convection is partially explained by the weakening of the climatological northeasterly flow from the Mediterranean (see below, Sect. 5.6). Here, in order to gain insight into the proposed mechanism from 3-D AGCM simulations, Fig. 10 presents jointly the upper (200 hPa, second row) and lower ( $850 \mathrm{hPa}$, fourth row) streamfunction anomalies. In $850 \mathrm{hPa}$ response are apparent the alterations in the local-ITCZ (Fig. 10d, h, l): an anomalous cyclone in the WAM domain at CNRM and UCM forcing deepupward motions; but an anticyclonic anomaly along Central African Republic and Guinean coastline in IPSL. 
Fig. 9 July-September vertical-meridional cross sections of the 3-D wind field modeled by CNRM (top), UCM and IPSL (bottom) after averaging the results between $20^{\circ} \mathrm{W}$ and $30^{\circ} \mathrm{E}$. Arrows refer to the $\mathrm{v}$ and omega components and isolines to the $u$ component. Red/black contours each $2 \mathrm{~m} / \mathrm{s}$ for positive/negative $u$ values. Left control runs. Middle Cold minus control differences with shadings when the zonal wind is positive. Right Warm minus control differences. Arrows and shadings for significant signals from a paired- $t$ test at $p=0.05$ (a) 3D wind (CNRM): CTL

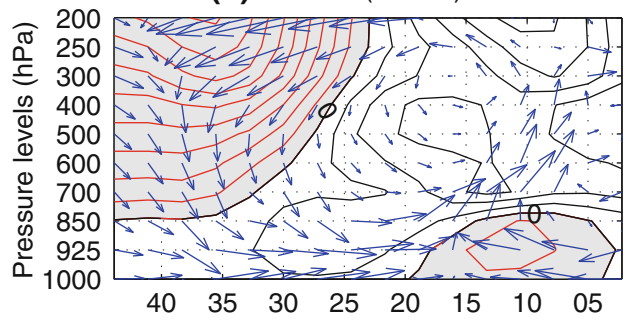

(c) $3 \mathrm{D}$ wind $(\mathrm{UCM}): \mathrm{CTL}$

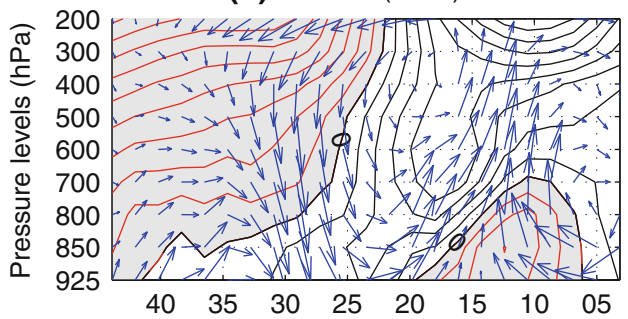

(e) $3 D$ wind (IPSL): CTL

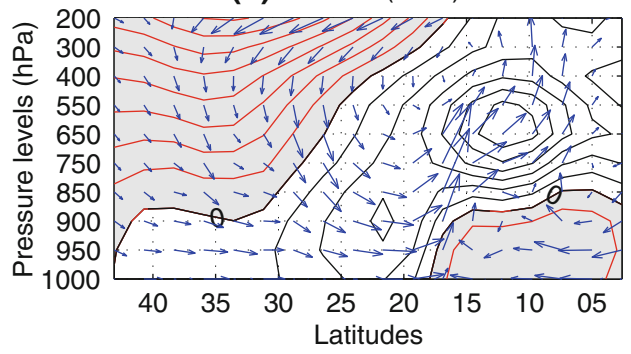

(b) Warm-CTL

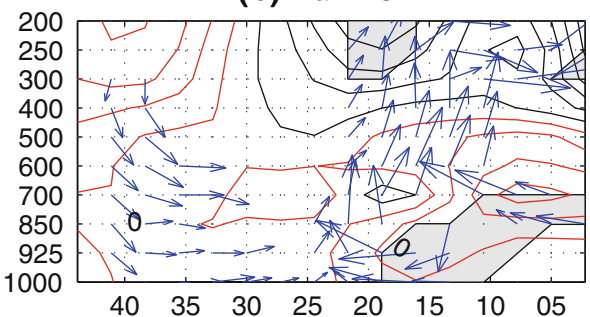

(d) Warm-CTL

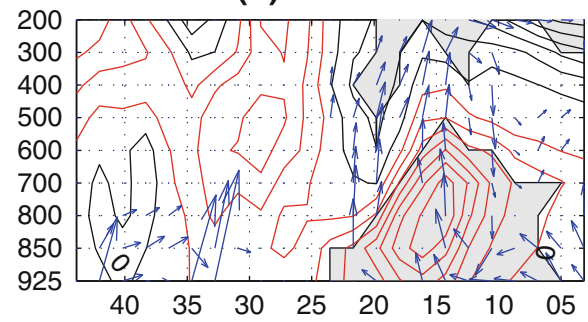

(f) Warm-CTL

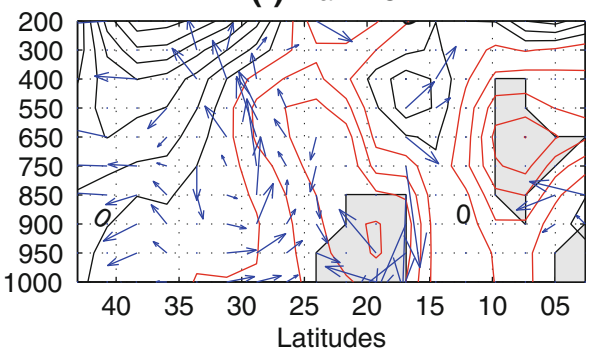

It is also noticeable the low-level negative anomalies surrounding the eastern Mediterranean basin, associated with negative pressure anomalies there and in accordance with the observational work by Raicich et al. (2003). This feature, the low-level convergence anomaly, would go along with Peyrillé et al. (2007) regarding the decrease of NE winds in response to warming of Mediterranean SST (see Sect. 5.6); and partially in contrast to Rowell (2003) and Jung et al. (2006) who found no change in the circulation leading to enhanced monsoon precipitation.

Additionally, this anomalous low-level convergent inflow is associated with positive streamfunction anomalies at upper-levels, revealing a baroclinic structure in the atmosphere (Fig. 10b, f, j): along the whole subtropical belt in CNRM, confined into the eastern Mediterranean in UCM, and isolated over the Arabian Peninsula in IPSL. Similar thermally-driven response to changes in the Mediterranean SST has been reported by $\mathrm{Li}$ (2006), who found a circumglobal wintertime-teleconnection initiated in the Mediterranean basin. Experiments analyzed here seem to corroborate this direct global-response to Mediterranean summer forcing (García-Serrano et al. manuscript in preparation); while previous evidences support this finding (Jung et al. 2006).

\subsection{Moisture fluxes}

Figure $11 \mathrm{a}, \mathrm{b}$ focuses better on the zonal and meridional mean moisture fluxes in low and mid troposheric layers using all the CNRM runs, i.e., 20 control and 20 warm simulations. Only the CNRM is chosen for taking advantage of the good vertical resolution of this model (45 vertical levels) particularly in low layers (Salas-Mélia et al. 2005). This approach is not extrapolable to other models but it provides valuable insights.

The moisture transport is mainly organized with a SW maximum at $925 \mathrm{hPa}$ by $10^{\circ} \mathrm{N}$ (positive values in panels a, b) and an easterly maximum at $700 \mathrm{hPa}$ around $10^{\circ} \mathrm{N}$, hence just under and southward to the main AEJ axis, as shown by the negative values in Fig. 11a. Warm-CTL composites in Fig. 11c, d present larger significant signals. In particular the zonal moisture transport by the AEJ is shifted northward (negative/positive dipolar patterns at $700 \mathrm{hPa}$ in Fig. 11c) while in lower levels, negative/ positive differences northward/southward to $20^{\circ} \mathrm{N}$ in Fig. $11 \mathrm{c}, \mathrm{d}$ reveal a significant increase of northeasterly and southwesterly monsoonal flux. This finding implies an enhanced deep convection in the WAM area. Additional analyzes (not reported here) have shown that the increase 
(a) psi200 in JAS: CTL (CNRM)

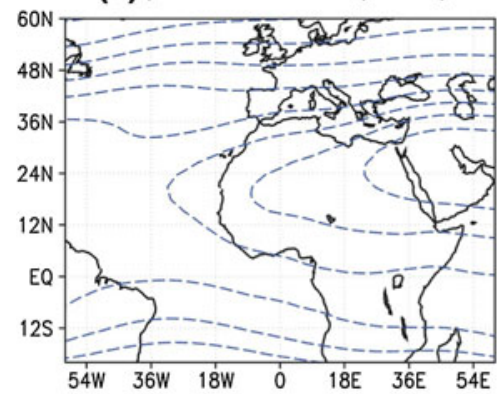

(b) psi200 Warm-CTL

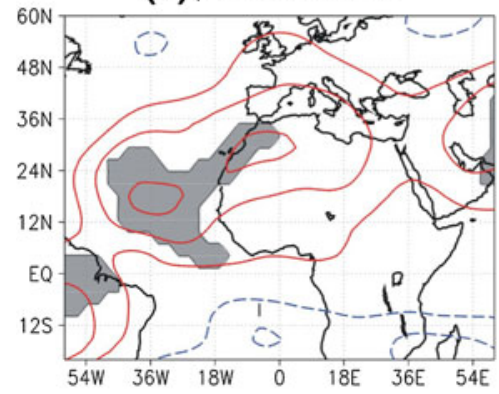

(c) psi850 in JAS: CTL (CNRM)

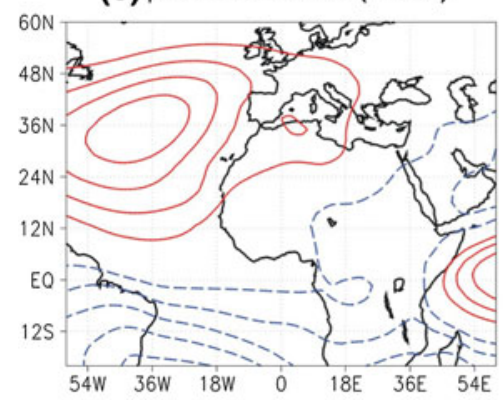

(d) psi850 Warm-CTL

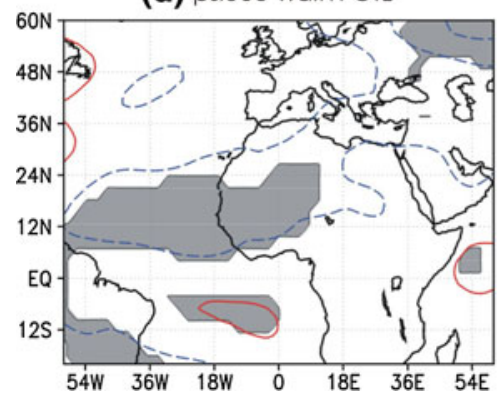

(e) psi200 in JAS: CTL (UCM)

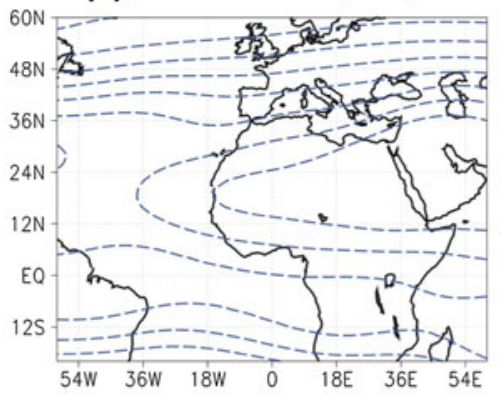

(f) psi200 Warm-CTL

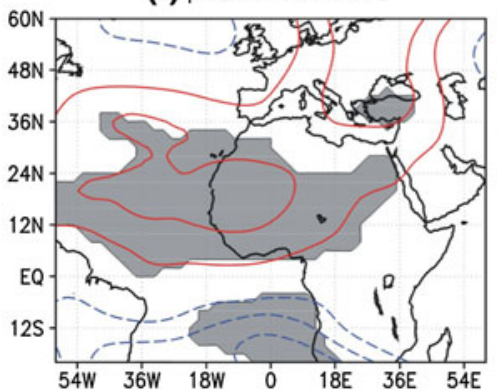

(g) psi850 in JAS: CTL (UCM)

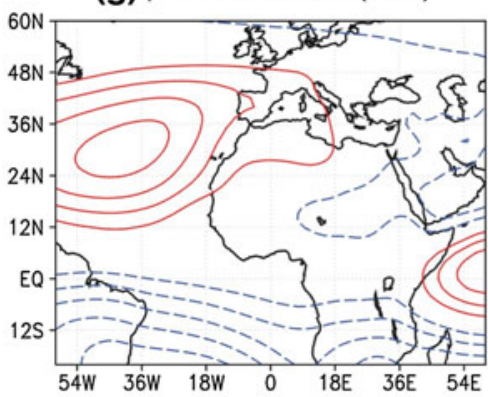

(h) psi850 Warm-CTL

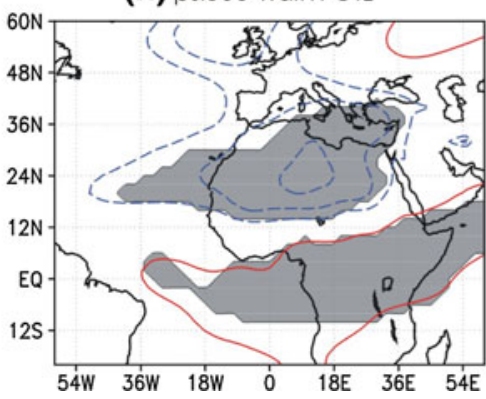

(i) psi200 in JAS: CTL (IPSL)

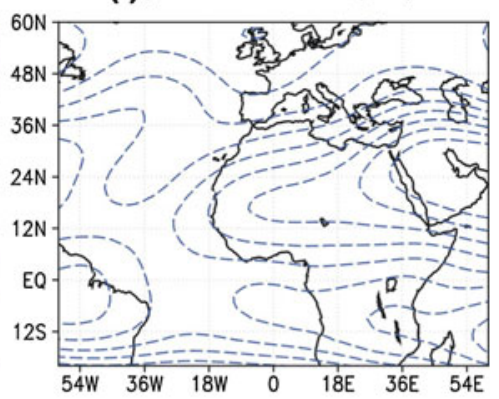

(j) psi200 Warm-CTL

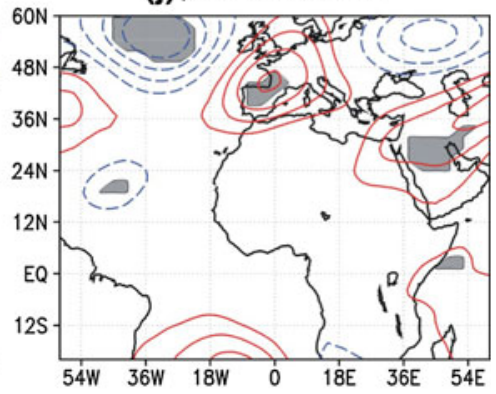

(k) psi850 in JAS: CTL (IPSL)

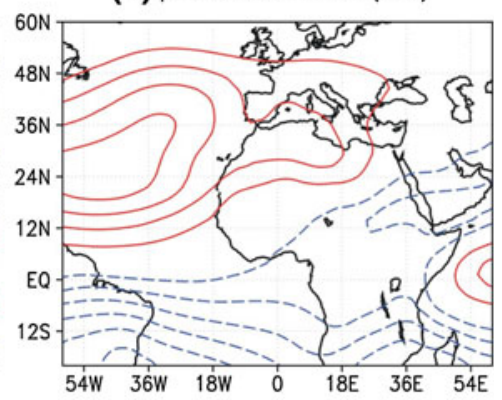

(I) psi850 Warm-CTL

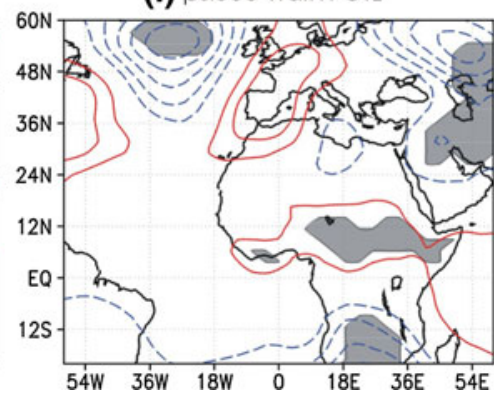

Fig. 10 July-September streamfunction composite at $200 \mathrm{hPa}$ (first and second rows) and $850 \mathrm{hPa}$ (third and fourth rows) from CNRM (left), UCM (middle) and IPSL (right). First $\left(\mathrm{ci}=1.0 \times 10^{7} \mathrm{~m}^{2} / \mathrm{s}\right)$ and Third $\left(\mathrm{ci}=3.0 \times 10^{6} \mathrm{~m}^{2} / \mathrm{s}\right)$ rows: control runs. Second

in northeasterly moisture flux is mainly due to an augmentation of the specific humidity in low-level over the warmer eastern Mediterranean. This strengthens the flux and together with the reinforcement of the southwest monsoon augments moisture convergence in low levels, according to Rowell (2003). This feedback mechanism would also help to the anomalous northward displacement (ci $\left.=0.8 \times 10^{6} \mathrm{~m}^{2} / \mathrm{s}\right)$ and Fourth $\left(\mathrm{ci}=0.3 \times 10^{6} \mathrm{~m}^{2} / \mathrm{s}\right)$ rows: warm experiments. Here the shadings refer to significant differences regarding a Student $t$ test at $p=0.05$

of the ITCZ, providing above-average precipitation over the Sahel.

\subsection{Response in low levels}

To assess better the capabilities of the 3 models to reproduce correctly the tropical-subtropical circulation over the 
Fig. 11 July-September vertical-meridional cross sections of mean and composite moisture fluxes from CNRM over the longitudinal window $20^{\circ} \mathrm{W}-30^{\circ} \mathrm{E}$. (a, b): u and v mean components from the control runs; (c, d): composite differences between the warm and control simulations. The solid (dashed) contours refer to the positive (negative) differences. In (c, $\mathbf{d})$, shadings are superimposed when composite differences are significant at $p=0.10$ regarding a Student $t$ test (a) u moisture flux (CNRM): CTL

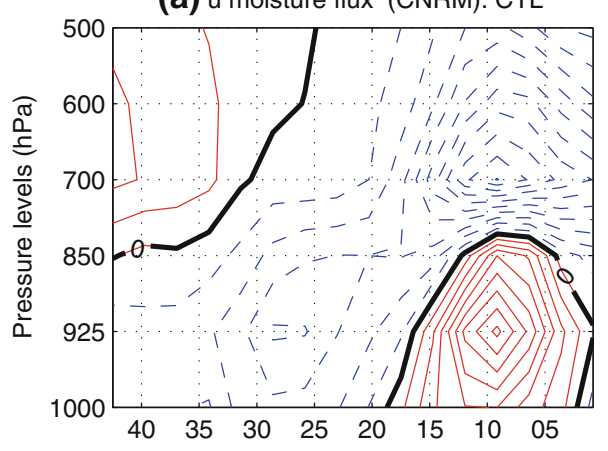

(c) Warm-CTL: u flux

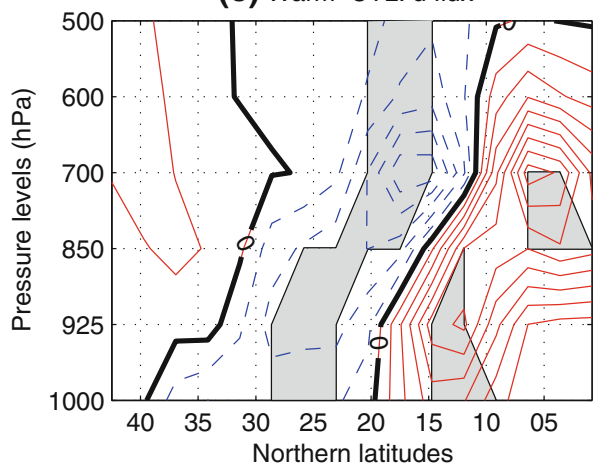

(b) v moisture flux (CNRM): CTL

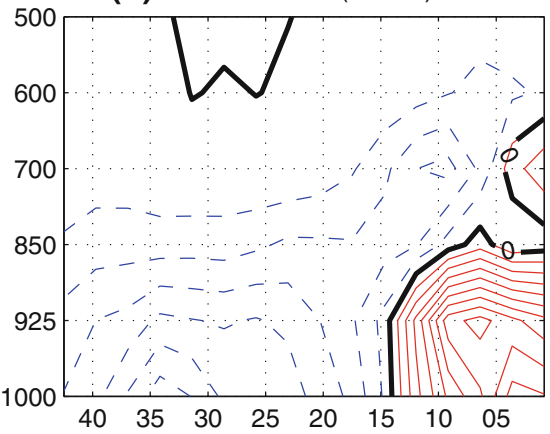

(d) Warm-CTL: v flux

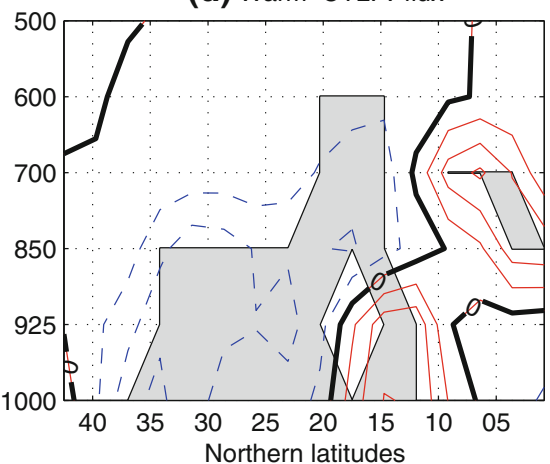

Mediterranean-African window, Fig. 12a, c, e displays the mean low level wind fields as produced in the control simulations. The skill of simulations is rather good since several key-elements are reproduced and well located, i.e., Azores and Ste Helena anticyclonic gyres, monsoon and Harmattan systems, ITCZ...

The Warm-CTL significant differences at $p=0.10$ are presented in Fig. 12b, d, f with shadings when the $\mathrm{v}$ component is positive. The 3 models give anomalous surface westerlies over the Sahelian area, although the location of the signals is different from one model to another. Thus, CNRM concentrates the strongest signals over the Atlantic (under $12^{\circ} \mathrm{N}$ ) and the eastern Sahel, UCM over a large part of the West African continent north to the equator and subtropical Atlantic $\left(12-24^{\circ} \mathrm{N}\right)$, while IPSL produces significant westerlies in the Sahelian domain but with a similar amplitude south of the equator. Despite these differences, common features emerge from the multimodel approach (Fig. 12g, h). This multi-model ensemble retains large anomalous westerlies coming inland from the Atlantic (Rowell 2003) and reaching the Sahel region, but does not take into account the southerly component from Gulf of Guinea. Additionally, as also shown in each model (Fig. 12b, d, f), the weakening of the climatological northeasterly flow from the eastern Mediterranean is apparent. These anomalous surface winds have a clear southerly component east of $10^{\circ} \mathrm{E}$ over Egypt. This feature is consistent with the anomalous low-level convergence in the southeastern Mediterranean basin, as discussed above (Fig. 10d, h, 1), and is in agreement with Peyrillé et al. (2007) regarding the penetration decrease of the mean circulation depending on the thermal contrast between the African continent and the Mediterranean Sea (or SSTforced in this case).

\subsection{Response in mid and high levels}

Figures 13 and 14 present the mean and composite wind fields at 600 and $200 \mathrm{hPa}$, respectively, with shadings where the zonal component is positive (blows eastward). In the top-middle panels are ensemble responses for each model, while in bottom panels are presented the multimodel approach (Figs. 13, 14g, h). At 600-200 hPa the control experiment (Figs. 13, 14a, c, e) reproduces correctly several specific features of the upper and mid level circulation, i.e., the AEJ and TEJ main axes over West Africa, the subtropical westerly jet pattern over the Mediterranean, and at $600 \mathrm{hPa}$ northerlies from the Mediterranean. Warm experiments (Figs. 13, 14b, d, f) cause (1) a significant reduction of subtropical westerlies in high levels south of the equator; (2) a significant increase in TEJ, more clearly seen in each model behaviour than multi-model ensemble, confined to 0 and $15^{\circ} \mathrm{E}$; and (3) a relative decrease in AEJ, with clear distinct location in each model which causes a diffuse signal in the multi-model ensemble. All of these features are known to be favourable to the 
(a) W925 in JAS: CTL(CNRM)

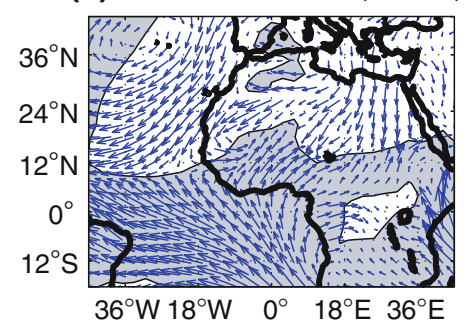

(b) Warm-CTL

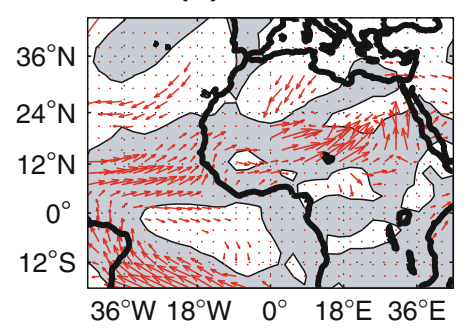

(c) W950 in JAS: CTL(UCM)

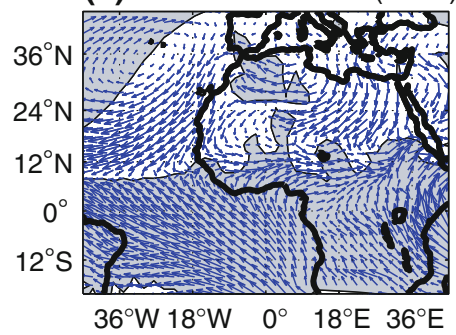

(d) Warm-CTL

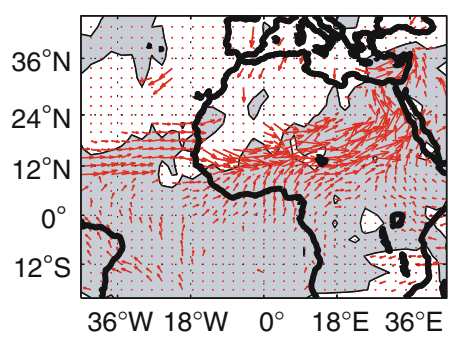

(e) W low level in JAS: CTL(IPSL)

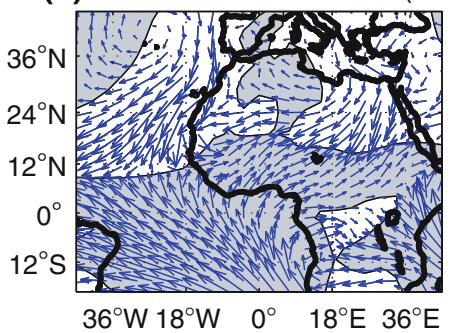

(f) Warm-CTL

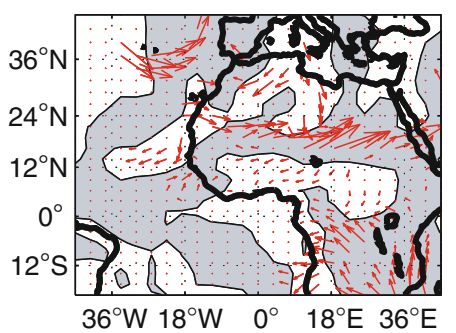

(g) W950 speed and div in JAS: ALL CTL

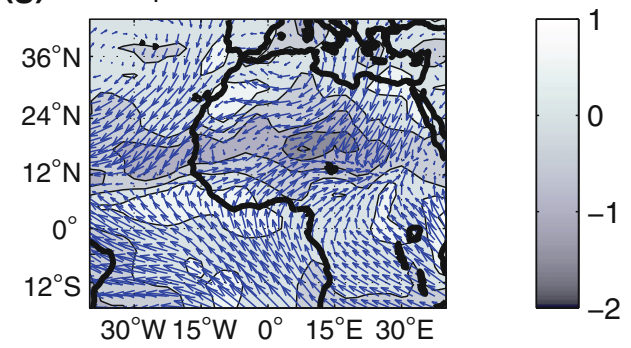

Fig. 12 Top July-September mean wind fields in low levels $(925 \mathrm{hPa}$ ) from CNRM (left), UCM (middle) and IPSL (right) experiments; control runs with positive meridional wind shaded. Middle: Warm minus control differences. Here the shadings refer to significant differences regarding a Student $t$ test at $p=0.10$. Bottom

monsoon circulation (Newell and Kidson 1984; Fontaine et al., 1995).

\section{Discussion and conclusion}

The purpose of this study was twofold: (1) reexamining the observed relationship between the Mediterranean thermal variability (Western and Eastern basins) and Sudan-Sahel rainfall estimates over the recent period, i.e., not marked by long wet and dry phases (as in the 50-70 s); (2) reporting some rainfall and atmospheric impacts generated by warm JAS anomalies in the Mediterranean Basin using multimodel sensitivity experiments. The results provide from both empirical and numerical ensemble approaches. The analyses use 3 types of datasets: in situ observations (rainfall, sea surface temperature...), satellite estimates (GPCP, CMAP data) and reanalyzed data from the NCEP-DOE

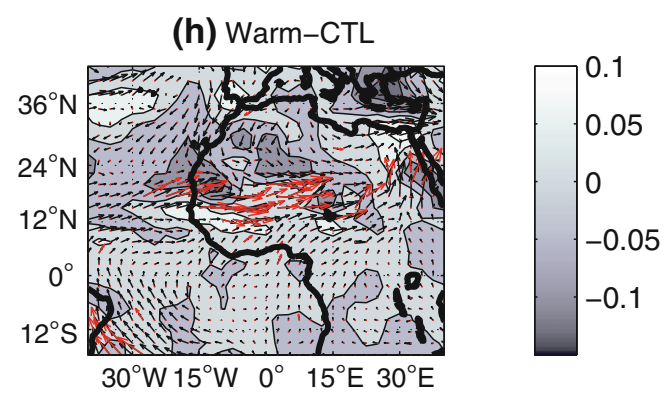

Multi-model ensemble of wind (arrows) and horizontal divergence (contours) fields at $950 \mathrm{hPa}$; mean (left) and Warm minus Control composite (right). Red arrows are superimposed when the differences on (h) are significant at $p=0.10$ regarding a Student $t$ test. Contours refer to the positive (negative) differences in divergence

AMIP II (winds and specific humidity on isobaric surfaces...).

Considered together the statistical and numerical results let suppose the existence of a thermal forcing of the Mediterranean on the African monsoon. Basically Mediterranean warming, with maximum amplitude in the eastern basin, leads to enhanced moisture convergence and therefore rainfall over Sudan-Sahel latitudes in agreement with Rowell (2003) who reports also a strengthening of moist advection across the Eastern Sahara by the mean flow. Peyrillé et al. (2007) insist more on a reduction of northerlies both in magnitude and extension, compatible with a deeper northward migration of the ITCZ into the continent. In accordance with the latter, Raicich et al. (2003) evidenced that the Sahel monsoonal season is associated with below-normal surface pressure in the eastern Mediterranean. All above has been also verified here, implying that this Mediterranean-WAM connection 
(a) W600 in JAS: CTL(CNRM)

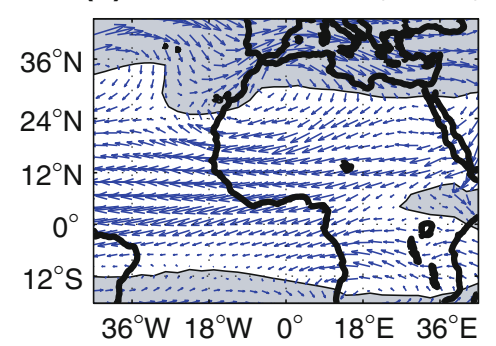

(b) Warm-CTL

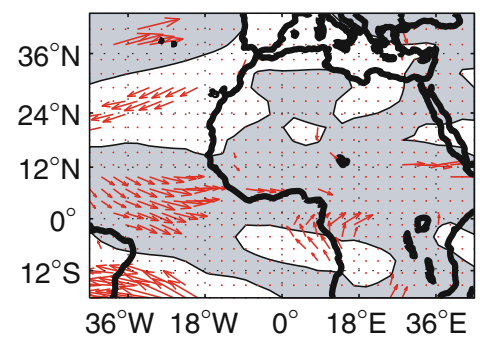

(c) W600 in JAS: CTL(UCM)

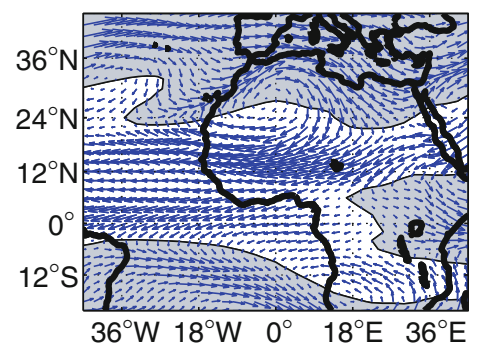

(d) Warm-CTL

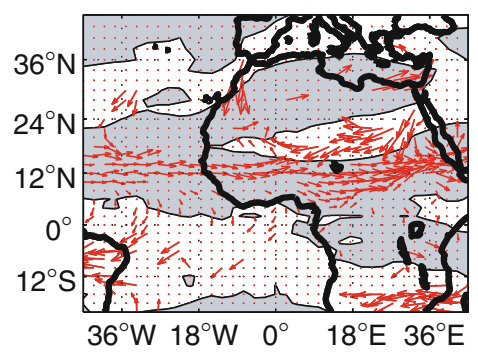

(e) W600 in JAS: CTL(IPSL)

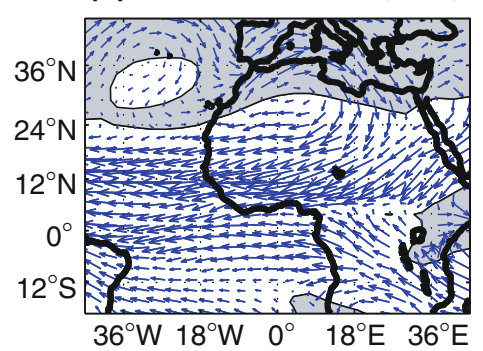

(f) Warm-CTL

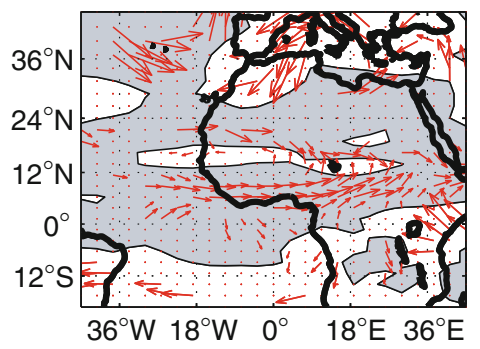

(g) W600 in JAS: ALL CTL

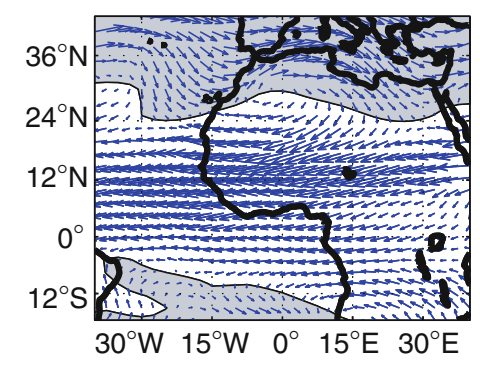

(h) Warm-CTL

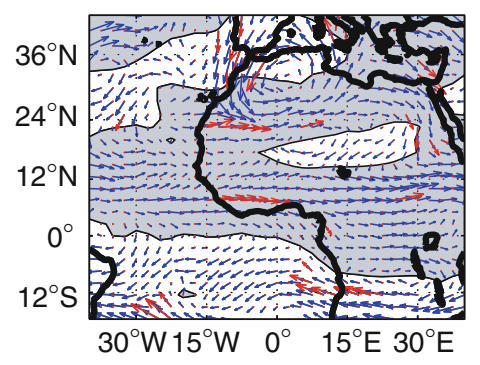

Fig. 13 As Fig. 12 but for horizontal flow at $600 \mathrm{hPa}$. Shading underline positive values

was robust during recent decades. Thus, when the warming concerns the East basin, a strong link with Sahel precipitation has been found, involving the reinforcement of both the ITCZ-deep motion and westerly transport of humidity thereby, in short, strengthening the main WAM circulation regime. An open question to be addressed concerns the WAM teleconnection with the West basin. Our observational analysis suggests a relationship with deep convection over Gulf of Guinea, possibly related to the Atlantic equatorial SST mode.

The empirical results allowed us to discuss the linearity and significance of the relationship. They can be summarized in 3 points.

(1) The Eastern Mediterranean concentrates the highest SVD temperature variance, while a large continental region, located somewhat northward to the mean ITCZ position, accumulates the strongest loadings in terms of enhanced deep convection and ascendance. This connection has been found in both synchronous and 1 month-lead performances, suggesting an important influence of the East basin on the WAM system.

(2) Additional results have confirmed the existence of a 1 month delay between thermal variability in the Mediterranean and deep convection over Africa. There are also preferred time scales for correlations, i.e., synoptic variability ( $<10$ days) and AEWs (35 days). This last connection is mainly observed eastward to the $0^{\circ}$ longitude, a region known for a long time as an area of AEW development. These features will be also further analysed in the future through AGCMs and WRF simulations.

(3) When the Eastern basin is abnormally warm the northward migration of the monsoon system and ascendances around the ITCZ reinforce through deeper moist convection south of the Sahara. These air ascents strengthen northerlies at $200 \mathrm{hPa}$ and hence the monsoon cell, air descents above the Southern Tropics and low level moist winds from the South. 
(a) W200 in JAS: CTL(CNRM)

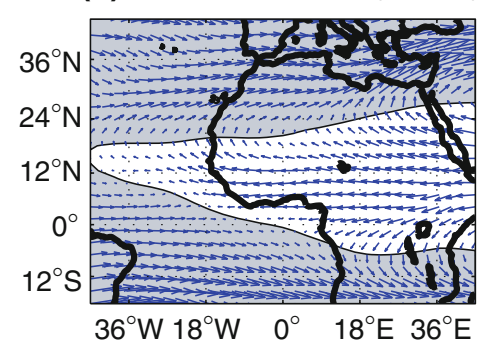

(b) Warm-CTL

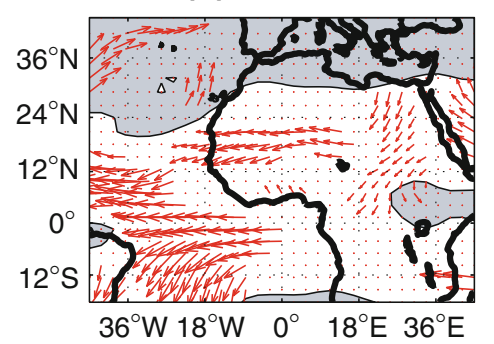

(c) W200 in JAS: CTL(UCM)

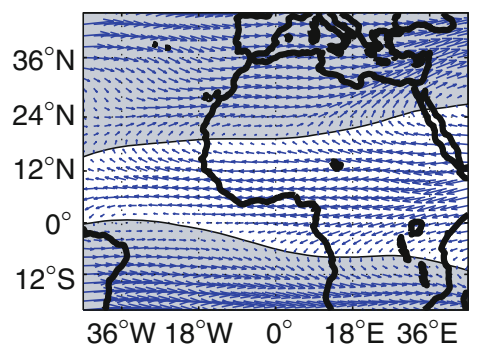

(d) Warm-CTL

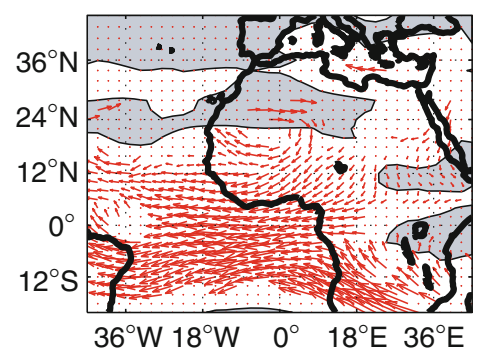

(e) W200 in JAS: CTL(IPSL)

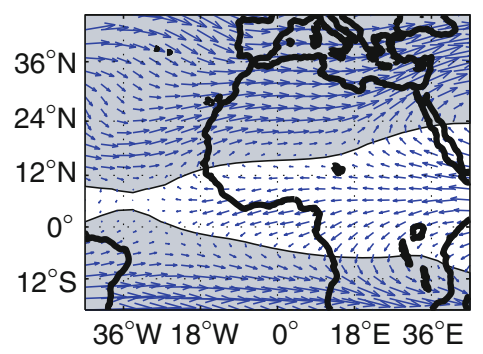

(f) Warm-CTL

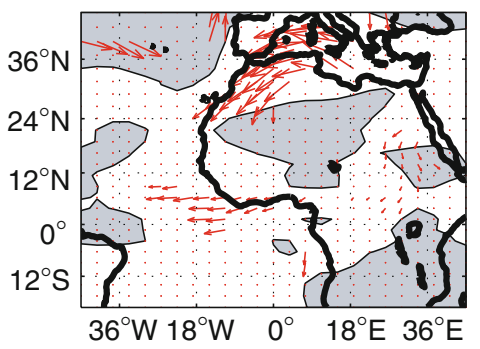

(g) W200 in JAS: ALL CTL

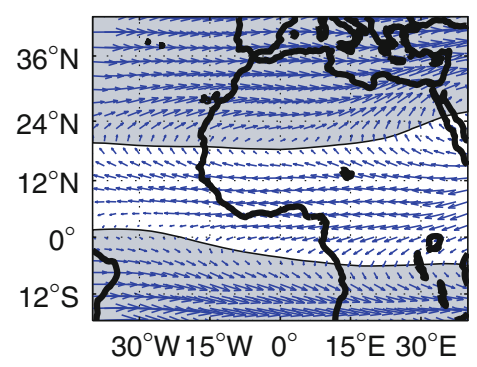

(h) Warm-CTL

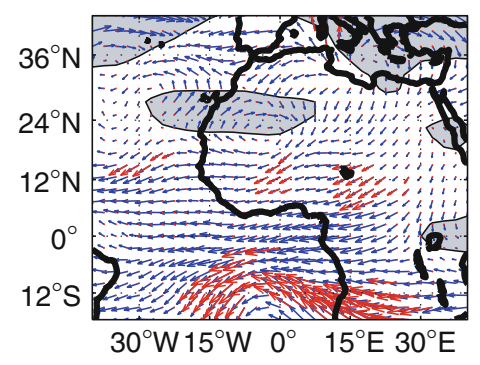

Fig. 14 As Fig. 12 but for horizontal flow at $200 \mathrm{hPa}$. Shadings underline positive values

This increases moisture transport under $400 \mathrm{hPa}$ over the continent $\left(5-20^{\circ} \mathrm{N}\right)$, low level convergence via the SW monsoonal flow in the Sahel zone and hence rainfall surplus just northward to the rain belt in JulySeptember. Additional analyses (not produced here) and Fig. 3 show that the reverse tends to occur in cold situations, in accordance with Rowell (2003).

The SST sensitivity experiments linked to normal, warm and cold situations over the Mediterranean and performed on four AGCMs allowed us first to illustrate the relative good accuracy of the models to reproduce the May-September evolution of several key-elements of the monsoon circulation. The more reliable latitudinal-migration of the rainbelt climatology has been found for CNRM and UCM models.

Second, in the models the response between warm and cold situations in the Eastern Mediterranean is not symmetric: the sensitivity experiments showed that warm occurrences impact more on West African precipitation than cold ones. In fact, cold-SST runs have not been conclusive, becoming separated from the linear hypothesis of
Rowell (2003). Perhaps, it is because of the AGCM difficulty for well simulating the reduced-latent heat release in cold situations. It is also important to mention that climatological summer SST conditions in the Mediterranean Sea resemble a zonal gradient with maximum located in the eastern basin quite similar to forcing fields prescribed in the simulations (not shown). Hence, the MediterraneanSahel connection in cold conditions continues being an issue to be explored. By contrast, the positive empirical relationship between warm SSTs in the Mediterranean and the West African monsoon can be interpreted in terms of thermal Mediterranean forcing.

In this way, warm experiments generate an enhancement of the southern meridional cell in low and high levels, related to reinforced monsoonal southwester lies, a more northward location of its ascending branch (ITCZ) over West Africa in association with more (less) intense monsoon and TEJ (AEJ). It is however important to bear in mind that such changes in the overturning circulation are not necessarily directly forced by Mediterranean SST since the enhanced moisture transport from the Mediterranean 
into the Sahel region increases also the latent heat and diabetic heating. This tends to fuel the rising motion in the WAM area and subsequently the downward motion in the overturning circulation.

An integrating picture has been evidenced from AGCM simulations presented here. According to Rowell (2003) and Fontaine et al. (2003), the favoured humidity transport from the Mediterranean Sea into ITCZ is accompanied by both anomalous surface-influx from the tropical Atlantic and reduced export via AEJ at mid-levels (two of the Rowell's feedbacks). The former could help to displace more northward the WAM-deep convection up to the Sahelian region. In addition, another mechanism has been shown contributing to this anomalous poleward ITCZ-extension. Consistent with the lower-tropospheric convergence found in the southeastern Mediterranean basin, which could explain the surface pressure anomalies suggested by Raicich et al. (2003), is the weakening of the climatological northeasterly flow east of $10^{\circ} \mathrm{E}$ over Egypt. This finding is in agreement with the penetration decrease of the mean circulation depending on the thermal contrast between African continent and the Mediterranean Sea (or SSTforced in the simulations; Peyrillé et al. 2007). This feature reflects a substantial northward migration of the monsonal rainbelt, and hence above-normal precipitation over the Sahel. This result does not contradict the anomalous moisture transport originated in the Mediterranean; since although weakened, the additional evaporation would be advected southward across the eastern Sahara by the flow.

Acknowledgments The authors are very grateful to the anonymous reviewers for their interesting comments, and to the National Center for Atmospheric Research (USA), Climate Prediction Centers and the National Oceanic and Atmospheric Administration for providing the data. J. G.-S. greatfully acknowledge the founds from the ESFMedCLIVAR Programme of grants (E.G/1694). The study was mainly supported by the Global change and Ecosystems programme (EU Integrated project: African Monsoon Multidisciplinary Analysis (AMMA) and the French component of AMMA. Based on a French initiative, AMMA was built by an international scientific group and is currently funded by a large number of agencies, especially from France, UK, US and Africa. It has been the beneficiary of a major financial contribution from the European Community's Sixth Framework Research Programme. Detailed information on scientific coordination and funding is available on the AMMA International web site http://www.amma-international.org.

Open Access This article is distributed under the terms of the Creative Commons Attribution Noncommercial License which permits any noncommercial use, distribution, and reproduction in any medium, provided the original author(s) and source are credited.

\section{References}

Adler RF, Huffman GJ, Chang A, Ferraro R, Xie PP, Janowiak J, Rudolf B, Schneider U, Curtis S, Bolvin D, Susskind J, Arkin P, Nelkin E
(2003) The version 2 global precipitation climatology project (GPCP) monthly precipitation analysis (1979-present). J Hydrometeorol 4(6):1147-1167. doi:10.1175/1525-7541(2003)004< 1147:TVGPCP $>2.0 . \mathrm{CO} ; 2$

Fontaine B, Janicot S, Moron V (1995) Rainfall anomaly patterns and wind field signals over West Africa in August (1958-1989). J Clim 8(6):1503-1510. doi:10.1175/1520-0442(1995)008<1503: RAPAWF $>2.0 . \mathrm{CO} ; 2$

Fontaine B, Roucou P, Trzaska S (2003) Atmospheric water cycle and moisture fluxes in the West African monsoon: mean annual cycles and relationship using NCEP/NCAR reanalyses, Geophys Res Lett, 30, 3, doi: 10.1029-10.1032

Joly M (2008) Rôle des oceans dans la variabilité vclimatique de la mousson ouest africaine, $\mathrm{PhD}$ dissertation, 200 pages, CNRM/ GAME, Météo-France, Toulouse

Jung T, Ferranti L, Tompkins AM (2003) Response to the Summer of Mediterranean SST Anomalies over Europe and Africa. J Clim 2006(19/20):5439-5454

Kanamitsu M, Ebisuzaki W, Woolen J, Yarg S-K, Hnilo JJ, Fiorino M, Potter GL (2002) NCEP-DOE AMIP-II reanalysis (R-2). Bull Am Meteorol Soc 83:1631-1643. doi:10.1175/BAMS-83-111631(2002)083<1631:NAR > 2.3.CO;2

Li LZX (2006) Atmospheric GCM response to an idealized anomaly of the Mediterranean Sea surface temperature. Clim Dyn 27:543-552. doi:10.1007/s00382-006-0152-6

Louvet S, Fontaine B, Roucou P (2007) Which rainfall dataset can be used to study African monsoon at intra-seasonal timescale? Technical Note, 3 tables, 10 figures, 27 pages. CRC, Dijon. http://www.ubourgogne.fr/climatologie/AMMA_D1.1.3/other_ rainfall_product.htm

Mitchell TD, Carter TR, Jones PD, Hulme M, New M (2004) A comprehensive set of high-resolution grids of monthly climate for Europe and the globe: the observed record (1901-2000) and 16 scenarios (2001-2100). Tyndall working paper 55, Tyndall Centre, UEA, Norwich, UK. http://www.tyndall.ac.uk/

New M, Lister D, Hulme M, Makin I (2002) A high-resolution data set of surface climate over global land areas. Clim Res 21:1-25. doi: $10.3354 / \mathrm{cr} 021001$

Newell RE, Kidson JE (1984) African mean wind changes between Sahelian wet and dry periods. J Climatol 5:27-33

Peyrillé P, Lafore JP (2007) An idealized two-dimensional framework to study the West African monsoon. Part II: large-scale advection and the diurnal cycle. J Atmos Sci 64:2783-2803. doi: 10.1175/JAS4052.1

Peyrillé P, Lafore JP, Redelsperger JL (2007) An idealized twodimensional framework to study the West African monsoon. Part I: validation and key controlling factors. J Atmos Sci 64:27652782. doi:10.1175/JAS3919.1

Polo I, Rodríguez-Fonseca B, Losada T, García-Serrano J (2008) Tropical Atlantic Variability modes (1979-2002). Part I: timeevolving SST modes related to West African rainfall. J Clim (in press). doi:10.1175/2008JCLI2607.1

Raicich F, Pinardi N, Navarra A (2003) Teleconnections between Indian monsoon and Sahel rainfall and the Mediterranean. Int $\mathbf{J}$ Climatol 23:173-186. doi:10.1002/joc.862

Rodwell MJ, Hoskins B (1996) Monsoons and the dynamics of deserts. QJR Meteorol Soc 122:1385-1404. doi:10.1002/qj. 49712253408

Rowell DP (2003) The Impact of Mediterranean SSTs on the Sahelian Rainfall Season. J Clim 16:849-862. doi:10.1175/1520-0442 (2003)016<0849:TIOMSO > 2.0.CO;2

Salas-Mélia D, Chauvin F, Déqué M, Douville H, Gueremy JF, Marquet P, Planton S, Royer JF, Tyteca S (2005) Description and validation of the CNRM-CM3 global coupled model, CNRM working note 103., available at http://www.cnrm. meteo.fr/scenario2004/references_eng.html 
Xie P, Arkin PA (1997) Global precipitation: a 17-year monthly analysis based on gauge observations, satellite estimates, and numerical model outputs. Bull Am Meteorol Soc 78:2539-2558. doi:10.1175/1520-0477(1997)078<2539:GPAYMA > 2.0.CO;2

Xie P, Janowiak JE, Arkin PA, Adler RF, Gruber A, Ferraro R, Huffman GJ, Curtis S (2003) GPCP pentad precipitation analyses: an experimental dataset based on gauge observations and satellite estimates. J Clim 16:2197-2214. doi:10.1175/ 2769.1

Yin X, Gruber A, Arkin PA (2004) Comparison of the GPCP and CMAP merged gauge satellite monthly precipitation products for the period 1979-2001. J Hydrometeorol 5:1207-1222. doi: 10.1175/JHM-392.1 